IZA DP No. 4848

The Gender Pay Gap in Top Corporate Jobs in Denmark: Glass Ceilings, Sticky Floors or Both?

Nina Smith

Valdemar Smith

Mette Verner

March 2010 


\title{
The Gender Pay Gap in Top Corporate Jobs in Denmark: Glass Ceilings, Sticky Floors or Both?
}

\author{
Nina Smith \\ Aarhus University \\ and IZA \\ Valdemar Smith \\ Aarhus School of Business \\ Mette Verner \\ Danish School of Media and Journalism \\ Discussion Paper No. 4848 \\ March 2010 \\ IZA \\ P.O. Box 7240 \\ 53072 Bonn \\ Germany \\ Phone: +49-228-3894-0 \\ Fax: +49-228-3894-180 \\ E-mail: iza@iza.org
}

Any opinions expressed here are those of the author(s) and not those of IZA. Research published in this series may include views on policy, but the institute itself takes no institutional policy positions.

The Institute for the Study of Labor (IZA) in Bonn is a local and virtual international research center and a place of communication between science, politics and business. IZA is an independent nonprofit organization supported by Deutsche Post Foundation. The center is associated with the University of Bonn and offers a stimulating research environment through its international network, workshops and conferences, data service, project support, research visits and doctoral program. IZA engages in (i) original and internationally competitive research in all fields of labor economics, (ii) development of policy concepts, and (iii) dissemination of research results and concepts to the interested public.

IZA Discussion Papers often represent preliminary work and are circulated to encourage discussion. Citation of such a paper should account for its provisional character. A revised version may be available directly from the author. 


\section{ABSTRACT \\ The Gender Pay Gap in Top Corporate Jobs in Denmark: Glass Ceilings, Sticky Floors or Both?*}

This paper analyses the gender gap in compensation for CEOs, Vice-Directors, and potential top executives in the 2000 largest Danish private companies based on a panel data set of employer-employees data covering the period 1996-2005. During the period, the overall gender gap in compensation for top executives and potential top executives decreased from 35 percent to 31 percent. However, contrary to many other studies, we do not find that the gender gap for Danish top executives disappears when controlling for observed individual and firm characteristics and unobserved individual heterogeneity. For CEOs, the raw compensation gap is 28 percent during the period while the estimated compensation gap after controlling for observed and unobserved characteristics increases to 30 percent. For executives below the CEO level, the estimated compensation gap is lower, ranging from 15 to 20 percent. Thus, we find evidence of both glass ceilings and sticky floors in Danish private firms.

JEL Classification: J33, M52, J16

Keywords: CEO compensation, gender gap, glass ceiling

Corresponding author:

Nina Smith

School of Economics and Management

Aarhus University

Bartholins Allé 10

Building 1326

DK-8000 Aarhus C

Denmark

E-mail: nsmith@econ.au.dk

\footnotetext{
*Financial support from the The Danish Research Council for Independent Research, Social Sciences (FSE) is gratefully acknowledged. We also thank participants and discussants at the $10^{\text {th }}$ Workshop on Corporate Governance and Investment held in Copenhagen 2009 and participants and discussants at the Southern Economic Association Annual Meeting held in San Antonio 2009 for helpful comments. Thanks to Joachim Borg Kristensen who has been extremely helpful as research assistant on the project.
} 


\section{Introduction.}

The proportion of women who reach top positions in Danish private firms is low compared to other EU countries. In 1996, only 3 percent of the CEOs in the largest Danish private firms were women. Ten years later, in 2005 , this figure had increased to 5 percent. This may come as a surprise since Denmark was one of the first countries in OECD where women entered the labour market and became full time members of the workforce. Denmark was also one of the first Western countries which introduced extensive high quality public childcare as part of a political strategy of equal opportunities for men and women in the labour market in the 1960s and early 1970s, see OECD (2002). In 2006, Denmark was in a clear lead with respect to the coverage of publicly provided formal care for children aged 0-3 years, see EU Commission (2009). Hence it seems a paradox that Denmark is not doing very well in international comparisons of overall gender compensation gaps, the proportion of women on private boards or the number of women in top executive positions, see EU Commission (2009) and Terjesen and Singh (2008). Denmark is ranked as number 7 (of 134 countries) on the overall "Gender Gap Index" (see World Economic Forum (2009)), but when it comes to the gender gap for representation among "legislators, senior officials and managers", Denmark is ranked low as no. 68 .

In a recent study, Gupta, Smith and Oaxaca (2006) have found that Danish women in the top of the wage distribution, incl. top executives, have been sliding down in the wage distribution during the latest decades, when controlling for observed qualifications. Exactly the opposite is found for a comparable group of US women. One of the hypotheses presented in the study by Gupta et al. is that the extended use in Denmark of family friendly policies which imply absence from work for shorter or longer periods (maternity leave, care days for sick children etc) is much more harmful for top managers and other high skilled women compared to women at the bottom of the labour market. If there exist severe potential boomerang effects of family friendly policies, we expect that these effects should be more widespread in the top of hierarchy of private firms, i.e. among top executives such as CEOs and Vice-Directors.

This paper analyses the gender pay gap in top corporate jobs in the 2000 largest Danish private companies based on a panel of employer-employees data covering the period 1996-2005. The motivation for analysing the gender pay gap for this group is twofold. Firstly, we want to shed light on the potential effects of having children and other household responsibilities on the gender compensation gap in top corporate jobs. There exists a large empirical literature on the gender wage 
gap in the labour market in general, but very little empirical evidence for the group of top executives in private companies. Secondly, since a number of studies suggest that gender diverse boards may improve firm performance, it should be expected that the gender gap in top executives' compensation is decreasing over time. The paper sheds light on the ongoing discussion on discrimination and the potential existence of a glass ceiling or sticky floors in the upper part of the labour market: Is the gender gap in compensation explained by qualifications and observed household related background characteristics, i.e. are female top executives still lacking behind their male peers because of less education, less employment experience, household responsibilities etc.? Or do some firms permanently pay higher salaries to female managers, irrespective of female characteristics, i.e. is unobserved heterogeneity in top managers' salaries mainly due to firm specific or individual specific factors?

The data set used in this study is a panel employer-employees data set on top managers and potential top managers in Danish private companies. We have very precise information on occupational status in the firm, i.e. whether the individual is the CEO, is Vice-director or has an occupational status within the firm just below these levels. For the last sample year 2005, the data include 1867 CEOs, 8261 Vice-Directors and 13,100 potential top executives. The data set is merged to administrative data on employees, and we have access to extensive information on firms as well as the households and spouses of the individuals that are included in our study.

There exists a limited number of empirical analyses on the gender pay gap among top executives. These studies tend to explain most of the observed gender pay gap by the fact that women do not reach the top and become a CEO or only get close to the top and become Vice-Director. Earlier studies are typically based on firm level data, often restricted to listed firms. The present study adds to the existing literature by being able to estimate compensation functions for the narrowly defined groups of CEOs and Vice-Directors, and potential CEOs and Vice-Directors, respectively, based on three large panel data sets which also include detailed information on household background.

In this study we find that the overall 'raw' gender compensation gap for top executives and potential top executives decreased from 35 percent to 31 percent during the period 1996-2005. However, when looking at the three separate groups, CEOs, Vice-Directors, and the pool of potential top executives and controlling for observed individual characteristics and unobserved time constant heterogeneity, the observed overall reduction of the gender compensation gap disappears. 
For CEOs, the reduction of the compensation gap was small and insignificant while for VD and potential top executives, the estimated gap even increased during the period 1996-2005. Further, for the small and selected group of CEOs, we find that controlling for unobserved individual characteristics the estimated gender compensation gap even increases the estimated gender compensation gap. We interpret this result as an indication that the very few females who reach top positions in private firms are a highly selected sample who on average deviates from their male colleagues with respect to unobserved factors as motivation, ambitions, abilities etc.

\section{CEO compensation and gender}

The gender pay gap is typically analysed within a human capital framework where variations in observed hourly wages are explained by variations in observed or unobserved human capital variables, like experience, education, effort, and ability etc. When it comes to top management compensation, the mechanism explaining a potential gender wage gap may be different from the traditional human capital approach. In the corporate governance literature, the compensation of CEOs is explained by factors like firm size, firm performance, and ownership of the firm, see for instance Murphy (1999). Theories on promotion into CEO positions as for instance the 'tournament theory', see Lazear and Rosen (1981), say that the top management compensation should be examined in the context of the organization's hierarchy and assessed by how effectively it stimulates performance throughout the company.

However, in order to explain why female top managers are often observed to have lower compensation relative to comparable male managers, additional theories have to be applied. The classical Becker theory on discriminatory tastes may offer one explanation of a potential gender wage gap among top managers. If the board of directors has discriminatory preferences, they may pay lower salaries to female CEOs, ceteris paribus, i.e. even though tournament arguments may also play an important role when determining the pay structure within the firm. However, the traditional argument against the Becker discrimination theory may also apply in this case: Discriminatory firms will in the long run be outperformed and/or female executive officers will leave discriminatory firms.

Lazear and Rosen (1990) offer a theory which does not rely on an assumption of discriminatory behaviour among employers or in the boardroom. They show that women may end up in lower paying positions even though they have the same ability distribution as their male colleagues. This 
result is based on the assumption that women have outside alternatives (in the household) where they are more productive than their male colleagues.

Coate and Loury (1993) present an alternative theory based on information asymmetries and statistical discrimination. Imprecise knowledge about the productivity of young women or their career preferences may lead to systematic underestimation of the productivity of this group. The uncertainty about female qualifications may be seen as an extra cost and may explain why these groups have lower earnings or are more seldomly promoted into top managerial positions. According to Coate and Loury (1993), statistical discrimination against women gives risk averse employers an incentive to offer women jobs with a lower level of on-the-job-training. Further, if women are aware of the existence of statistical discrimination in advance, this may discourage even well qualified potential CEOs from investing in skills and/or discourage them to apply for promotion or wage increases.

The theories by Lazear and Rosen and Coate and Loury may be considered explanations of why a 'glass ceiling' seems to exist for well qualified females who do not end up in top management positions even if they appear to be as well qualified as their male colleagues. However, according to Lazear and Rosen it should be expected that the relatively few women who are promoted into top positions, despite their gender, receive higher compensation growth due to promotion. Thus, the Lazear and Rosen, theory does not really explain why a gender gap in compensation should exist within narrowly defined groups of CEOs or Vice-Directors. According to the Lazear and Rosen theory we should expect that the relatively few women who reach the top are a highly selected group of women who are to a large extent single women, or they are married to spouses whose comparative advantages in household production more than outweigh their 'biological deficiencies' with respect to child birth etc.

A more recent theory moves the focus from the 'ceiling' to the 'floor'. The 'sticky floor theory', see Booth et al. (2003), assumes that females who are exposed to a discriminatory behaviour of the board of directors or the top management in the firm may not be able to move to another less discriminating firm if they have responsibilities in their private life. Married or cohabiting women with spouses who are also in top positions and women with young children may be less mobile compared to their male colleagues. If the firm is aware of these mechanisms (whether the explanation is lack of mobility or lack of outside job offers because of statistical discrimination) even non-discriminatory firms which have 'discovered' the true ability of a woman may not pay as 
high salaries as they would have done in case of a male with comparable characteristics or position within the firm. Alternatively, women are not promoted to the same extent as men. Thus, the firm can earn a rent since women executives have fewer outside opportunities due to the invisibility of their abilities or due to lack of mobility because of family responsibilities. ${ }^{1}$ This firm behaviour may explain why a permanent gender gap in compensation can exist. As in the case of the Lazear and Rosen theory, the spouse my also play an important role. Women who are married to a spouse having a high occupational position may be much less mobile and are not able to or willing to pursue their own career plans compared to single women or women who are married to spouses in lower paying job positions.

The glass ceiling theory and the sticky floor theory point to different mechanisms when explaining the observed gender pay gap among top managers, and it is not easy empirically to make a distinction between the two groups of theories. Yurtoglu and Zulehner (2009b) use the position in the overall compensation distribution as an indicator on whether it is a 'sticky floor' or a 'glass ceiling' effect: If the gender gap is in the lower part of the distribution, they consider the gap as explained by sticky floor mechanisms, and if the gap appears in the upper part of the distribution, they use the notion of 'glass ceiling'. Further, according to the sticky floor theory, we might expect that household responsibilities (i.e. having young children or more children, or having a husband who is also having a career) have a more negative impact on female top executives' compensation, compared to males' compensation. Glass ceiling effects may potentially harm all women, whether actually having children or not.

\section{Previous empirical studies}

One of the first studies which examined the gender wage gap in top management was the study by Bertrand and Hallock (2001) analysing the earnings of top five executives in a large sample of US firms listed by Standard \& Poor, covering the period 1992-97. Bertrand and Hallock found a considerable gender pay gap (around 44 percent). However, when controlling for a number of observed characteristics, most of the gender wage differential was 'explained' by observed factors as human capital variables, occupational level, industry, etc.

\footnotetext{
${ }^{1}$ A number of papers have recently focussed on different risk behaviour among male and female potential top managers as one of the reasons for observing fewer women in CEO positions and as an explanation of an observed gender pay gap at the upper end of the skill distribution, see Niederle and Vesterlund (2007) and Booth (2009).
} 
Bell (2005) used the same approach and an updated version of the same data set as Bertrand and Hallock (2005), now covering the years 1992-2003. She found that the compensation and promotion chances for female executives were significantly higher in women-led firms, i.e. there was a positive effect of female CEOs or female board chairmen on the salaries of female managers at lower levels in the firm. She explained this evidence by mentoring and supporting relations that more productive females select themselves into women-led firms because they expect to face (statistical) discrimination. Holst and Busch (2009) analyse the gender pay gap for managers in German firms based on SOEP data for the year 2006. They find that the overall percentage of women employed in the firm has a negative effect on the salaries of both male and female managers.

Two recent papers by Yurtoglu and Zulehner (2009a,b) use the OSIRIS data set on total compensation for top executive officers in listed US firms for the period 2001-07. In Yurtoglu and Zulehner (2009a) it is found that the gender compensation gap was reduced to 19 percent for this sample and after controlling for individual and firm characteristics, the gap is reduced to 7 percent. In Yurtoglu and Zulehner (2009b), a quantile regression approach is applied. They find larger estimated pay gaps at the bottom than at the top of the pay distribution. As in the former papers, the main explanation of the gender pay gap is differences in occupational positions, i.e. fewer women reach the top and highest paying positions in the firm.

Bertrand et al. (2009) analyse the compensation gender gap among MBAs graduating from University of Chicago during the period 1990-2006. They find that male and female MBAs seem to follow the same career track until first child is expected or born. After birth of first child, the career of mothers and fathers with an MBA from University of Chicago diverges: Male MBAs experience constantly increasing earnings while MBA mothers on average have slightly decreasing earnings after birth of first child. ${ }^{2}$ However, the analysis also indicates large differences between the female MBAs. Women married to spouses with lower earnings work more hours and have shorter periods out of the labour force compared to women who are married to high-earning' spouses. For women without children, the effect of being married to a high-earning spouse was positive. These results indicate that it is extremely important to control for factors related to household characteristics and

\footnotetext{
${ }^{2}$ The same result is found in some studies on marital wage premium, see for instance Gupta et al. (2007).
} 
allocation of work between spouses when explaining the gender gap in compensation for CEOs and other top managers in private companies.

\section{Data}

The data set is a merged employer-employees unbalanced panel sample of the about 2000 largest Danish companies observed during the period 1996-2005. The companies are private firms, i.e. they are not part of the public sector. The firms may be privately owned or listed firms. The data set is selected from registers in Statistics Denmark. The information on firms is merged with individual information on the employees of the firm, including information on background characteristics of the spouses for employees who are either legally married or cohabiting. The register information from administrative registers is further merged with information from a private Danish data account data register, Experian (previously Kфbmandsstandens Oplysningsbureau).

The sample is selected by Statistics Denmark's registers as the largest Danish firms, defined by total capital of the firms during each of the years 1996-2005. We delete all firms which do not have any employees, for instance holding companies etc. From these firms, we select all the CEOs and ViceDirector and potential CEOs (i.e. individuals who are in the occupational positions just below the CEO levels) observed as being employed at least one year in the selected firms during the period 1996-2005. The definition of the three categories of managers in our study is based on the available information in Statistics Denmark's registers ${ }^{3}$ :

- CEO: The CEOs in a firm with more than 50 employees. Given our definition, there is only one CEO in a firm.

- Vice-director (VD): Top executive with an overall responsibility in a given area within the firm (restricted to firms with more than 50 employees).

- Potential CEO or VD: 'Pool of potentials' consists of employees with qualifications and occupational status below the CEO or VD level.

\footnotetext{
3 The exact definition using the Statistics Denmark's 'DISCO-codes' is: CEO=Executive director (RAS-DISCO code 121, 1210). VD=Vice-Director (DISCO 122, 123, 1221-1239). Pool of potentials=Potential executives (CEO or VD). (First digit of DISCO code is 1 but not included in the groups of top or vice directors). The registration of the DISCO codes in the administrative registers has been improved during the observation period. In order to remove outliers or errors in the DISCO codes, we restrict the CEO group to individuals who are observed with an annual earnings in top 10 of the firm and Vice-Director are further restricted to individuals who are observed among the top 25.
} 
By these definitions of top managers we end up having in total 198,686 observations during the period 1996-2005, of whom 20,264 were CEOs, 82,270 were Vice-Directors, and 96,152 were categorized as being member of the pool of potentials, see Table 1 in Section 4.

The dependent variable in this study is annual compensation which is measured by the (log) annual earnings (DKK), $E_{i j t}$. Annual earnings are defined as the total earnings including bonuses etc. during the year as registered by the tax authorities. This measure excludes pension payments from the firm, non-taxable fringe benefits, stock options etc. on which we are not able to get reliable information. According to Bechmann (2008), 29 percent of Danish listed firms offered an option program in 2005 as part of the compensation for the top management. The proportion has been increasing since the late 1990s, see Eriksson (2001). Since these firms are among the largest Danish firms, we expect that the proportion is considerably lower in the sample selected for this study. The value of the option program changes over time and therefore, it is not obvious how to incorporate this information in a study of the gender pay gap. However, the results in Bechmann (2008) show a positive correlation between cash payments and the value of the option based compensation. This implies that by restricting the analysis to earnings defined as cash payments, the results in this study is expected to underestimate the gender gap. This expectation is supported by the study by Yurtoglu and Zulehner (2009a) who find that the gender pay gap is larger for the equity-based compensation component than for the fixed salary component. Table 2 below presents the 'raw', i.e. the simple average ratio between female and male earnings in each of the years for the three groups of employees.

The included explanatory variables in the estimations represent individual $\left(X_{i t}\right)$ as well as firm specific $\left(X_{j t}\right)$ characteristics, and variables reflecting spouse characteristics and whether the firm is more or less 'women-led':

- $X_{i t}$ : 'Classical human capital' variables as employment experience, experience squared, educational level. Employment experience is measured as the accumulated number of years spent in employment. Periods in part time employment are counted as half of full time employment. We are not able to measure over time work or individuals holding more than one job as the employment variables are based on pension payments to a compulsory pension scheme (ATP). Education level is measured by three indicators for educational level allowing for non-linear effects of education. Excluded category is no education beyond 
compulsory school Child variables are indicators for number of children (1, 2, and 3+) and an indicator for a child aged less than 3 years in the household. Excluded category is "no children'.

- $X_{j t}$ : Firm size is measured by number of employees, an indicator for being listed on stock exchange, firm profits ROE (Return On Equities), industry indicators (Energy, Building and construction, Hotel and restaurants, Transportations and telecommunications, Finance) and female proportion of employees.

- Women-led $d_{j t}$ : Indicators for being employed in a firm with a female director on the board or a female CEO.

- Spouse $_{i t}$ : Occupational level of the spouse (high level salaried, low level salaried, skilled, unskilled, self-employed, others), and an indicator for the spouse being a CEO. Excluded category is 'single', i.e. individuals who are not currently married or cohabiting.

Sample means for 2005 of all variables included in the estimations are shown in Appendix Table A1.

\section{The gender gap in top management}

Table 1 shows the development in the female proportion of CEOs, Vice-Directors, and in the Pool of Potential top managers. There is a clear development with respect to the female representation in top management in Danish companies during this period. In 1996, the female shares in the three groups were 23 percent in the Pool of Potentials, 9 percent in Vice-Director and 3 percent in the group of CEOs. These figures which are consistent with earlier Danish studies, see Smith et al. (2006) are fairly low in an international perspective.. However, in all three categories, the proportion of women has increased substantially, especially in the CEO and VD groups, where the female proportion increased by about 60 percent during the period.

The overall gender compensation gap decreased from 35 percent to 31 percent during the period 1996-2005, see Table 2. Within each of the two sub-groups, CEOs and VDs, the gender compensation gap was decreasing. Especially for CEOs, there was a dramatic equalization of compensation. In 1996, the gender gap was observed to 36 percent and in 2005 it was reduced to 13 percent! However, the very few female top CEOs included in the sample (less than 100 in each of the years) implies a large variation in the observed 'raw' gap. For Vice-Director, the gap is reduced 
during the observation period from 20 percent to 17 percent, while for the Pool of Potentials the gap has varied between 18-22 percent with no signs of a decreasing trend.

Table 1. Female proportion among CEOs, VDs and Pool of Potentials.

\begin{tabular}{cccc}
\hline & $\begin{array}{c}\text { 'Pool of } \\
\text { Potentials' }\end{array}$ & Vice-Director & CEOs \\
\hline 1996 & 0.229 & 0.090 & 0.031 \\
1997 & 0.232 & 0.090 & 0.035 \\
1998 & 0.243 & 0.096 & 0.033 \\
1999 & 0.252 & 0.102 & 0.032 \\
2000 & 0.308 & 0.111 & 0.038 \\
2001 & 0.311 & 0.112 & 0.043 \\
2002 & 0.326 & 0.125 & 0.042 \\
2003 & 0.324 & 0.129 & 0.045 \\
2004 & 0.345 & 0.133 & 0.045 \\
2005 & 0.324 & 0.145 & 0.053 \\
\hline No of obs.1996-2005 (all: 198,686) & 96,152 & 82,270 & 20,264 \\
Proportion 1996-2005 (all: 1.00) & 0.49 & 0.41 & 0.10 \\
\hline No of obs. 2005 (all: 23,228) & 13,100 & 8,261 & 1,867 \\
\hline Proportion in 2005 (all: 1.00) & 0.56 & 0.36 & 0.08 \\
\hline
\end{tabular}

Compared to the results for other countries, the gender compensation gap for Danish CEOs is fairly low. For the US, Bertrand and Hallock found a raw gender compensation gap of 44 percent for US top 5 CEOs (Standard \& Poor's ExecuComp data). Bell (2005), using data on top 5 CEOs from Standard \& Poor's 500, Midcap 400 and Smallcap 600 found a raw gender earnings gap of 25.4 percent for the period 1992-2003. The structure of the Danish gender pay gap among top managers also looks very different from what is found for the US in Yurtoglu and Zulehner (2009b) where the largest gender pay gap is found at the lower end of the compensation distribution while the gender pay gap is found to be lowest at the upper end of the compensation distribution. 
Table 2. The gender gap in compensation (annual earnings). ${ }^{1)}$

\begin{tabular}{lcccc}
\hline & All & $\begin{array}{c}\text { 'Pool of } \\
\text { Potentials' }\end{array}$ & Vice-director & CEO \\
\hline 1996 & 0.350 & 0.226 & 0.197 & 0.360 \\
1997 & 0.337 & 0.202 & 0.182 & 0.390 \\
1998 & 0.334 & 0.218 & 0.167 & 0.351 \\
1999 & 0.338 & 0.208 & 0.173 & 0.274 \\
2000 & 0.326 & 0.216 & 0.150 & 0.234 \\
2001 & 0.333 & 0.219 & 0.161 & 0.235 \\
2002 & 0.334 & 0.221 & 0.188 & 0.197 \\
2003 & 0.320 & 0.208 & 0.152 & 0.190 \\
2004 & 0.321 & 0.199 & 0.159 & 0.196 \\
2005 & 0.309 & 0.212 & 0.169 & 0.125 \\
\hline
\end{tabular}

1) The gender gap is calculated as $1-E_{f t} / E_{m t}$, where $E_{f t}$ and $E_{m t}$ are average female and male annual earnings in year $t$ respectively.

In Table 3, the main characteristics of the male and female managers in our sample are shown for the year 2005. There are significant differences between men and women for most of the variables. However, for the group of CEOs the picture is slightly different. Female CEOs have about the same labour market experience as their male colleagues, and somewhat surprisingly, they do also have about the same number of children (the differences are not statistically significant). ${ }^{4}$ For ViceDirectors and the Pool of Potentials, the average female working experience is significantly lower than their male colleagues, and the average number of children is about the same as for female CEOs. However, women in the Pool of Potentials are on average younger female CEOs, and thus, their completed fertility may end up being higher than that for female CEOs.

Female VDs, potential top managers (and to some extent CEOs but here the difference is not significant) tend to be singles to a much larger extent than male top managers. 25 percent of the female Vice-Directors are singles while this figure is only 10 percent for male Vice-Directors. If women in these groups are married, they are more likely than male top managers to be married to a CEO, i.e. fewer women in top management positions tend to be married to a spouse with a lower position than herself. Female top managers or potential top managers tend to be in firms with a relatively high proportion of female employees. Finally, the probability that there is a female board member is larger for female CEOs and VDs compared to their male colleagues!

\footnotetext{
${ }^{4}$ It should be kept in mind that the small number of females may imply that only very large differences are statistically significant from zero.
} 
Table 3. Sample means. Selected variables 2005.

\begin{tabular}{|c|c|c|c|c|c|c|}
\hline & \multicolumn{2}{|c|}{ Pool of Potentials } & \multicolumn{2}{|c|}{ Vice-director } & \multicolumn{2}{|c|}{$\mathrm{CEO}$} \\
\hline & Male & Female & Male & Female & Male & Female \\
\hline Annual earnings, DKK & $\begin{array}{l}484,569 * \\
(247,453)\end{array}$ & $\begin{array}{l}381,740 * \\
(161,865)\end{array}$ & $\begin{array}{l}710,863^{*} \\
(376,241)\end{array}$ & $\begin{array}{l}590,532 * \\
(258,292)\end{array}$ & $\begin{array}{c}1,316,755^{*} \\
(884,624)\end{array}$ & $\begin{array}{c}1,151,673 * \\
(900,266)\end{array}$ \\
\hline Experience, years & $\begin{array}{l}21.43^{*} \\
(10.94)\end{array}$ & $\begin{array}{l}17.12 * \\
(9.64)\end{array}$ & $\begin{array}{c}22.93 * \\
(9.70)\end{array}$ & $\begin{array}{c}20.26 * \\
(9.11)\end{array}$ & $\begin{array}{c}24.22 \\
(10.33)\end{array}$ & $\begin{array}{l}23.64 \\
(8.89)\end{array}$ \\
\hline No of children & $\begin{array}{c}0.87 \\
(1.04)\end{array}$ & $\begin{array}{c}0.85 \\
(0.97)\end{array}$ & $\begin{array}{l}1.09 * \\
(1.10)\end{array}$ & $\begin{array}{l}0.92 * \\
(1.00)\end{array}$ & $\begin{array}{c}0.94 \\
(1.08)\end{array}$ & $\begin{array}{c}0.85 \\
(1.09)\end{array}$ \\
\hline Spouse CEO (0/1) & $\begin{array}{l}0.03 * \\
(0.17)\end{array}$ & $\begin{array}{l}0.10^{*} \\
(0.29)\end{array}$ & $\begin{array}{l}0.02 * \\
(0.15)\end{array}$ & $\begin{array}{l}0.11 * \\
(0.32)\end{array}$ & $\begin{array}{l}0.04 * \\
(0.20)\end{array}$ & $\begin{array}{l}0.15^{*} \\
(0.33)\end{array}$ \\
\hline Single $(0 / 1)$ & $\begin{array}{l}0.16^{*} \\
(0.37)\end{array}$ & $\begin{array}{l}0.24 * \\
(0.43)\end{array}$ & $\begin{array}{l}0.10^{*} \\
(0.31)\end{array}$ & $\begin{array}{l}0.25 * \\
(0.43)\end{array}$ & $\begin{array}{c}0.09 \\
(0.28)\end{array}$ & $\begin{array}{c}0.16 \\
(0.40)\end{array}$ \\
\hline Share of women in firm & $\begin{array}{l}0.32 * \\
(0.13)\end{array}$ & $\begin{array}{l}0.41 * \\
(0.14)\end{array}$ & $\begin{array}{l}0.30 * \\
(0.15)\end{array}$ & $\begin{array}{l}0.43^{*} \\
(0.19)\end{array}$ & $\begin{array}{l}0.32 * \\
(0.16)\end{array}$ & $\begin{array}{l}0.41 * \\
(0.19)\end{array}$ \\
\hline $\begin{array}{l}\text { Female board member in } \\
\text { firm }(0 / 1)\end{array}$ & $\begin{array}{c}0.16 \\
(0.36)\end{array}$ & $\begin{array}{c}0.18 \\
(0.39)\end{array}$ & $\begin{array}{l}0.18 * \\
(0.39)\end{array}$ & $\begin{array}{l}0.25 * \\
(0.43)\end{array}$ & $\begin{array}{l}0.21 * \\
(0.41)\end{array}$ & $\begin{array}{l}0.38 * \\
(0.49)\end{array}$ \\
\hline Female CEO $(0 / 1)$ & $\begin{array}{c}0.07 \\
(0.25)\end{array}$ & $\begin{array}{c}0.08 \\
(0.26)\end{array}$ & $\begin{array}{l}0.05^{*} \\
(0.22)\end{array}$ & $\begin{array}{l}0.10^{*} \\
(0.30)\end{array}$ & $\begin{array}{l}0.09 * \\
(0.29)\end{array}$ & $\begin{array}{l}1,00 * \\
(0,00)\end{array}$ \\
\hline
\end{tabular}

*) indicates significant gender difference (1 percent) in sample means.

\section{Empirical model and estimation strategy}

The basic empirical model is a 'standard Mincerian human capital function' where the main explanatory variables are education and labour market experience. An indicator for being a woman is included in order to estimate the gender compensation gap. Since the focus is managerial compensation, we also include a number of variables reflecting corporate governance effects, like firm size, performance and industry. We successively add a number of variables to the human capital model which are supposed to catch effects from family responsibilities and firm

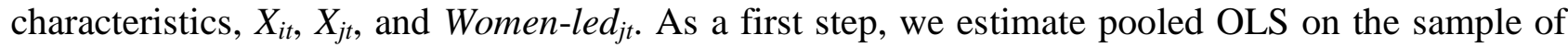
all top managers and including both males and females in all years. We add an indicator, $F$, for being female, and indicators for being CEO or VD in the company;

$$
\ln E_{i j t}=F_{i} \lambda+C E O_{i j t} \phi_{1}+V D_{i j t} \phi_{2}+X_{i t} \beta_{1}+X_{j t} \beta_{2}+D_{t} \gamma_{t}+\varepsilon_{i j t}
$$

where $D_{t}$ are time indicators. The error term $\varepsilon_{i t j}$ is - in the first step - assumed to be uncorrelated with included explanatory variables. As we use panel employer-employees data and observed the 
same individuals and firms many times in the data set, the error term is expected to be heteroscedastic. Therefore, we apply a robust estimator which corrects for heteroscedasticity. ${ }^{5}$ By adding more and more explanatory variables, we see how much of the raw gender earnings gap that may be explained by individual's own characteristics and firm characteristics.

However, the assumption behind the pooled OLS estimation in (1) may not be valid. Specifically, the indicators of main interest, $F, C E O$ and $V D$ may be correlated with the error term because of omitted variables. According to the theories described in Section 2, selection into the position as CEO or top manager may be a selective process which differs between men and women. A number of unobserved characteristics like effort and ambitions may be important, both for observed compensation and for the chance of becoming promoted into a VD or CEO position. If selection works differently for men and women, for instance due to discrimination or other unobserved mechanisms, this may bias the estimates of the coefficients of the female indicator $F$, and the indicators for occupational top positions, $C E O$ and $V D$. Thus, our estimates may not reflect causal effects.

The identification strategy in this study is to apply a robust panel estimator (Fixed Effect Vector Decomposition, FEVD estimator, see below) which captures the unobserved time constant variables. However, the 'fixed effect critique', see for instance Lundberg (2005) may also apply here. Some of the unobservables may change over time due to life cycle variation in career ambitions etc., and these changes which may affect career choices and compensation are not captured by the panel estimator. We try to address this time variant unobserved heterogeneity by adding exogenous controls that are expected to be correlated with the time variant unobservables in the compensation function. As candidates for being such control variables we select the career (occupational) position of the spouse in the previous year, and whether the individual was married or cohabiting, Spouse $_{i t-1}$ ). The career position of the spouse is expected to capture or proxy the current decisions within the household with respect to allocation of time and household responsibilities. ${ }^{6}$ If the individual changes marital status (in the previous year) or the spouse is promoted, we expect that these changes will reflect the lifecycle effects on preferences which are not captured by the FE or FEVD estimators. However, it might be argued that the spouse and

\footnotetext{
${ }^{5}$ The models are estimated by STATA procedures.

6 According to Bertrand et al. (2009) information on spouse's labour market career is a very good indicator for the career choices (labour supply behaviour and maternal leave periods) earlier in life.
} 
marital state variables are not exogenous to the outcome variable, the annual compensation, see for instance the discussion in Angrist and Pischke (2009). We use the lagged occupational spouse position in order to reduce problems of endogeneity. In order to evaluate the potential endogeneity problems which may still exist, we show a number of alternative estimations in order to indicate the robustness of our estimations.

The full model including both spouse variables as controls for the selection into top management position and time constant individual or firm specific effects $\left(\alpha_{i}\right.$ and $\left.\alpha_{j}\right)$ is:

$$
\ln E_{i j t}=F_{i} \lambda+C E O_{i j t} \phi_{1}+V D_{i j t} \phi_{2}+X_{i t} \beta_{1}+X_{j t} \beta_{2}+D_{t} \gamma_{t}+\text { Spouse }_{i t-1} \eta+\alpha_{i}+\alpha_{j}+\varepsilon_{i j t}
$$

The model in (2) is estimated by alternative panel estimators. Since one of the key variables, $F$, is time invariant and disappears in the fixed effects (FE) estimation, we also apply a random effects estimator (RE). These estimates are typically also inconsistent because the assumption that $\varepsilon_{i j t}$ is uncorrelated with included explanatory variables is violated. This assumption is tested by a Hausman test. As the assumption of independence is violated in most cases, we also apply a robust, but not unbiased, three stage estimator proposed recently by Plümper and Troeger (2007). The estimator, denoted Fixed Effect Vector Decomposition (FEVD), is useful in cases where the main interest is in the coefficients of time invariant or rarely time varying variables. This is the case for the indicator for being female $(F)$ and also the indicators for being top managers in the firm (CEO and $V D$ ) show little variation over time. The first step of the P\&T estimator is a FE estimation of (2). In the second step the individual specific average residuals from the FE are calculated and regressed on the time invariant or rarely time varying variables. In step 3 the full model is reestimated by pooled OLS and the residuals from step two are included as an additional regressor. In order to evaluate the robustness of the estimators, the results from alternative estimators are shown for the key coefficients in Table 5.

\section{OLS estimates of Gender gap in compensation}

As a first step, we present in Table 4 estimated coefficients of the parameter $\lambda$ in relation (1), i.e. the 'gender compensation gap', when correcting successively for more factors which may explain the 
annual earnings. The results which are comparable to many of the results found in previous empirical studies are based on robust pooled OLS estimations. ${ }^{7}$

Table 4. Gender gap in compensation:

Robust Pooled OLS estimates of the coefficient of the female indicator $(\lambda) .^{1}$.

\begin{tabular}{|c|c|c|c|c|c|c|}
\hline & \multicolumn{6}{|c|}{ Control variables included in estimation } \\
\hline & $\begin{array}{c}(0) \\
\text { Time } \\
\text { indicators }\end{array}$ & $\begin{array}{c}(1)= \\
(0)+ \\
C E O+V D\end{array}$ & $\begin{array}{c}(2)= \\
(1)+ \\
\text { CEO+VD } \\
\text { +spouse } \\
\text { controls }\end{array}$ & $\begin{array}{c}(3)= \\
(1)+ \\
\text { CEO+VD } \\
+ \text { spouse } \\
\text { controls } \\
+ \text { HC var }\end{array}$ & $\begin{array}{c}(4)= \\
(1)+ \\
\text { CEO+VD } \\
+ \text { spouse } \\
\text { controls } \\
+ \text { HC var } \\
+ \text { Child var }\end{array}$ & $\begin{array}{c}(5)= \\
(1)+ \\
\text { CEO+VD } \\
\text { +spouse controls } \\
+ \text { HC var } \\
\text { +Child var } \\
\text { +Firm var }\end{array}$ \\
\hline $\begin{array}{l}\text { Indicator for being } \\
\text { Female }\end{array}$ & $\begin{array}{l}-0.368 \\
(0.025)\end{array}$ & $\begin{array}{l}-0.218 \\
(0.016)\end{array}$ & $\begin{array}{l}-0.215 \\
(0.014)\end{array}$ & $\begin{array}{l}-0.173 \\
(0.011)\end{array}$ & $\begin{array}{l}-0.169 \\
(0.011)\end{array}$ & $\begin{array}{l}-0.170 \\
(0.008)\end{array}$ \\
\hline $\begin{array}{l}\text { R-squared } \\
\text { Number of obs. }\end{array}$ & $\begin{array}{c}0.077 \\
198,686\end{array}$ & $\begin{array}{c}0.339 \\
198,686\end{array}$ & $\begin{array}{c}0.359 \\
198,686\end{array}$ & $\begin{array}{c}0.436 \\
198,686\end{array}$ & $\begin{array}{c}0.440 \\
198,686\end{array}$ & $\begin{array}{c}0.481 \\
198,686\end{array}$ \\
\hline
\end{tabular}

1. All coefficients are significant at a 1 percent level.

Column (0) shows an estimated coefficient of -0.37 (i.e. a raw gender compensation gap of $37 \log$ points) when only time indicators are added to the model. When adding successively more explanatory variables, the estimated coefficient of $\lambda$ is reduced, but the coefficient seems to stabilize at a level around -0.17, i.e. an estimated gender compensation gap of around $17 \log$ points. The main drop in the numerical value of the $\lambda$-coefficient happens when adding indicators for being a CEO or a Vice-Director. The coefficient is reduced numerically from -0.37 to -0.22 . This result corresponds to most previous empirical analyses, see for instance Bertrand and Hallock (2001). However, our results are different from these studies in the sense that the estimated gender compensation gap does not become insignificant in the full model with all explanatory variables. Further, adding variables for number and age of children and firm characteristics virtually have no influence on the estimated gender compensation gap.

\section{Robustness - Alternative Panel Estimators}

The robust pooled OLS estimates in Table 4 may suffer from a number of deficiencies as discussed above. Therefore, in Table 5 alternative estimators of the gender pay gap are presented in order to evaluate the sensitivity and robustness of the estimators. Table 5 also adds the estimates of the indicators for having a position as CEO or as Vice-Director in the company.

\footnotetext{
7 The estimates are corrected for heteroscedasticity due to firm clusters by using the STATA procedure xtreg. In alternative estimations not shown here, heteroscedasticity corrections due to individual clusters are undertaken. The estimated standard errors are smaller in these estimations. The more conservative estimations are presented in Table 4.
} 
Table 5. Alternative estimates of indicators for being Female, CEO and Vice-Director ${ }^{1}$. Full model specification.

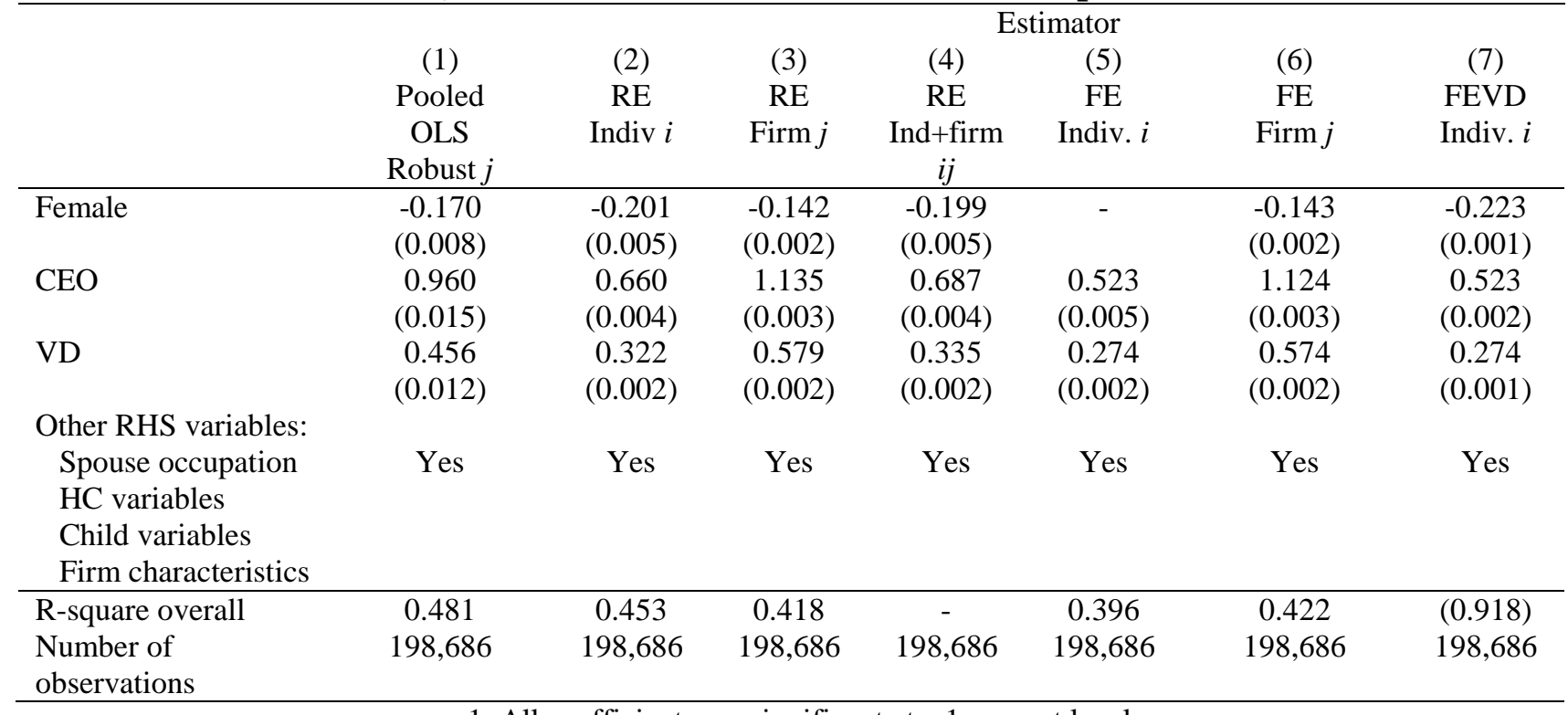

1. All coefficients are significant at a 1 percent level

The pooled robust OLS results in Column (1) in Table 5 are identical to the estimation of the full model in Column (5) in Table 4. Columns (2)-(4) show random effects estimated where individual, firm, and both individual and firm effects are accounted for, respectively, while Columns (5)-(6) show fixed effects estimates. ${ }^{8}$ Finally, the robust (but inconsistent) estimates by the fixed effect vector decomposition (FEVD) method controlling for individual specific effects are shown in Column (6). ${ }^{9}$

According to Table 5, the estimated gender gap in compensation for Danish top managers does not disappear when controlling for the full battery of explanatory variables and accounting for individual or firm specific unobserved time constant heterogeneity. The estimates of the indicator for being female range from -0.14 to -0.22 . All coefficients are highly significant. Thus, our results indicate there is still a considerable gender compensation gap among top managers when controlling for observed and unobserved individual and firm characteristics.

The estimated coefficients are clearly sensitive to the specification. The RE, FE, and the FEVD which control for individual specific effects (Columns 2,4,7).and the RE which controls for both

\footnotetext{
${ }^{8}$ The Hausman tests reject the overall hypothesis that the random effects estimates are consistent.

${ }^{9}$ The FEVD is only estimated for individual specific fixed effects not firm specific effects because the command xtfevd in STATA does not allow more observations on the same unit within a given year.
} 
firm and individual effects (Column 5) are fairly close. The estimated $\lambda$-coefficients in the RE and FEVD estimations are -0.20 and -0.22 , respectively. These coefficients are numerically larger than the pooled OLS estimate of -0.17 , i.e. controlling for unobserved individual specific factors like ability and ambitions, the gender compensation gap increases, or alternatively, some of the female (male) top managers have permanently high (low) values of the individual specific factors which affect their compensation positively (negatively). When controlling for these factors, the estimated gender gap increases, compared to pooled OLS estimates.

The RE and FE estimates which control only for permanent firm specific unobserved factors in Columns (3) and (6) are somewhat different. The estimated $\lambda$-coefficient is numerically lower, only -0.14 , compared to RE/FEVD estimates of -0.20 and -0.22 . This observation may reflect that some firms permanently tend to pay females (males) lower (higher) salaries when controlling for all observables, for instance due to variation in time constant preferences for discrimination or permanently gender biased information on skills and productivity, as proposed in the 'sticky floor' theory. However, the results in Columns 3, 4 and 6 also show that even when controlling for unobserved differences in firm behaviour (and in Column 6 also individual unobserved effects) there still exists a considerable compensation gap between male and female top executives. Thus, despite the results in Table 5 indicate that part of the gender gap can be explained by some firms permanently paying lower female executives lower salaries, a major part of the compensation gap remains unexplained.

In contrary to the $\lambda$-coefficients, the estimated coefficient of the two CEO and VD indicators are considerably (and tests show that the difference is significant) higher in RE and FE estimations where we control for unobserved firm heterogeneity, compared to pooled OLS and RE/FE/FEVD estimates with control for unobserved individual heterogeneity. Thus, some firms tend to pay permanently higher salaries to their top managers ${ }^{10}$.

Based on the results presented in Table 5, it is obvious that there are alternative estimates of the 'gender compensation gap' and that the size of the gap depends on choice of estimator. But in all cases, the estimated gap is significant and of a considerable size (lowest estimate is $14 \log$ points).

\footnotetext{
${ }^{10}$ The results from individual FE/RE/FEVD estimations of the VD and CEO are in line with the results found in Eriksson (1999) based on a different sample of Danish companies. Eriksson find a pay difference between CEO and VD level of around 30 percentage points in individual fixed effect estimations of annual compensation. Eriksson does not include gender indicators in his study.
} 
In line with most other studies, and for comparison reason, we prefer to use an estimator which only controls for individual specific effects. Further, the individual specific effect estimators allow us to reduce problems of endogeneity in the individual specific variables like human capital variables, child variables and the spouse control variables. Since the RE estimators are rejected by the Hausman test, and since the FE estimator with individual specific effects does not allow for an estimate of the $\lambda$-coefficient, the preferred estimator in the subsequent sections is the FEVD estimator which controls for individual specific unobserved heterogeneity and is robust though not consistent. However, note that the FEVD estimates for the CEO and VD-indicators are very close to the consistent FE estimates. In order to evaluate sensitivity of the estimates, we also present robust pooled OLS and RE estimates of $\lambda$ where relevant.

\section{Within Group Panel Estimates of the Gender Compensation Gap.}

The 'raw' figures on gender proportion and compensation gap in Tables 1-2 clearly showed that there has been a quite different development within the three groups of top managers and potential top managers. In this section, we dig deeper into this question and estimate the gender compensation gap within the three groups, i.e. the sample is split into the three groups, CEOs, VDs, and Pool of Potentials, and separate compensation functions are estimated for each of the three groups.

When splitting the sample into these groups, it is obvious that each of the groups may be selected samples of the population which may vary systematically with respect to unobservable characteristics, for instance ability and motivation. If ability is correlated with the included variables, for instance gender, the estimate of $\lambda$ will be biased, unless controlling for the unobservables, parallel to the problems of potential endogeneity when including indicators for being a CEO or VD in the estimations above. However, to the extent that the unobservables are time constant, a robust panel estimator like FEVD is expected to account for the selectivity problem. The results from pooled robust OLS, RE and FEVD estimates of the $\lambda$-coefficient within the three groups of managers are shown in Table 6. According to Table 6, our results are again fairly robust to choice of estimator with respect to the estimated $\lambda$-coefficient within the three groups of managers. 
Table 6 reveals that there are large variations within the three groups. ${ }^{11}$ The estimated gender compensation gap after controlling for all observables is largest among CEOs, amounting to about $30 \log$ points ( $\lambda$-coefficients in the range -0.29 to -0.33 ). It is lower for VDs, with a $\lambda$-coefficient in the range -0.17 to -0.21 and lowest in the 'Pool of Potentials', where the $\lambda$-coefficient is about minus 0.15 . These results are opposite to the results found for the US in Yurtoglu and Zulehner (2009b) where the largest gender pay gap was found at the bottom of the pay distribution and the smallest gap at the top of the distribution. Thus, our results indicate that there are both a glass ceiling and sticky floors, but the first effect is more pronounced than the latter.

\begin{tabular}{|c|c|c|c|}
\hline & $\begin{array}{l}\text { Pooled OLS } \\
\text { Robust } j\end{array}$ & $\begin{array}{c}\mathrm{RE} \\
\text { Individual } \\
\text { effects } i\end{array}$ & $\begin{array}{c}\text { FEVD } \\
\text { Individual } \\
\text { effects } i\end{array}$ \\
\hline $\mathrm{CEO}$ & $\begin{array}{c}-0.283^{*} \\
(0.040)\end{array}$ & $\begin{array}{l}-0.325^{*} \\
(0.027)\end{array}$ & $\begin{array}{c}-0.304 * \\
(0.007)\end{array}$ \\
\hline Vice-Director & $\begin{array}{l}-0.167^{*} \\
(0.010)\end{array}$ & $\begin{array}{l}-0.189 * \\
(0.007)\end{array}$ & $\begin{array}{l}-0.209^{*} \\
(0.002)\end{array}$ \\
\hline Pool of potentials & $\begin{array}{l}-0.150^{*} \\
(0.010)\end{array}$ & $\begin{array}{c}-0.151^{*} \\
(0.007)\end{array}$ & $\begin{array}{l}-0.161 * \\
(0.002)\end{array}$ \\
\hline $\begin{array}{l}\text { Other RHS variables: } \\
\text { Time indicators } \\
\text { Spouse occupation } \\
\text { HC variables } \\
\text { Child variables } \\
\text { Firm Characteristics }\end{array}$ & Yes & Yes & Yes \\
\hline
\end{tabular}

Compared to the 'raw' gender compensation gap in Table 2, it is interesting to note that the estimated gap in Table 6 is lower for the group of potential top managers (around 15 percent) compared to the 'raw' gap in Table 2 of about 20-22 percent. The opposite is observed for the group of top managers who are CEOs. According to Table 2, the raw compensation gap for CEOs decreased from 36 percent to 13 percent but the estimated compensation gap after controlling for observed and unobserved characteristics is around 30 percent (or more precisely 'log points'). This finding confirms the findings also found in Table 5 that the group of (female) CEOs is a highly selected group of females, who have been able to break the ceiling and become CEOs, and these women seem to have unobserved time invariant characteristics which affect their compensation positively. Since Table 2 indicated a large change in the raw gender compensation gap for this

\footnotetext{
${ }^{11}$ This is confirmed by formal F-tests on differences in coefficients between the three groups.
} 
group of CEOs, it is interesting to estimate the change in the gap during the observation period 1996-2005 in order to evaluate whether the raw figures in Table 2.

\section{Is the gender compensation gap changing over time?}

Figure 1 shows the estimated change in the gender compensation gap between 1996 and 2005. The estimation is based on the same model as in Table 6, Column 3, i.e. separate FEVD estimations on the three groups of top managers, except that an interaction term is added to the model, $F^{*} D_{t}$ in order to allow for a separate compensation development over time for male and female executives. Thus, the interaction terms estimates the (cumulative) change in the gender compensation gap.

Figure 1. Estimated Gender Gap in Compensation ${ }^{1}$.

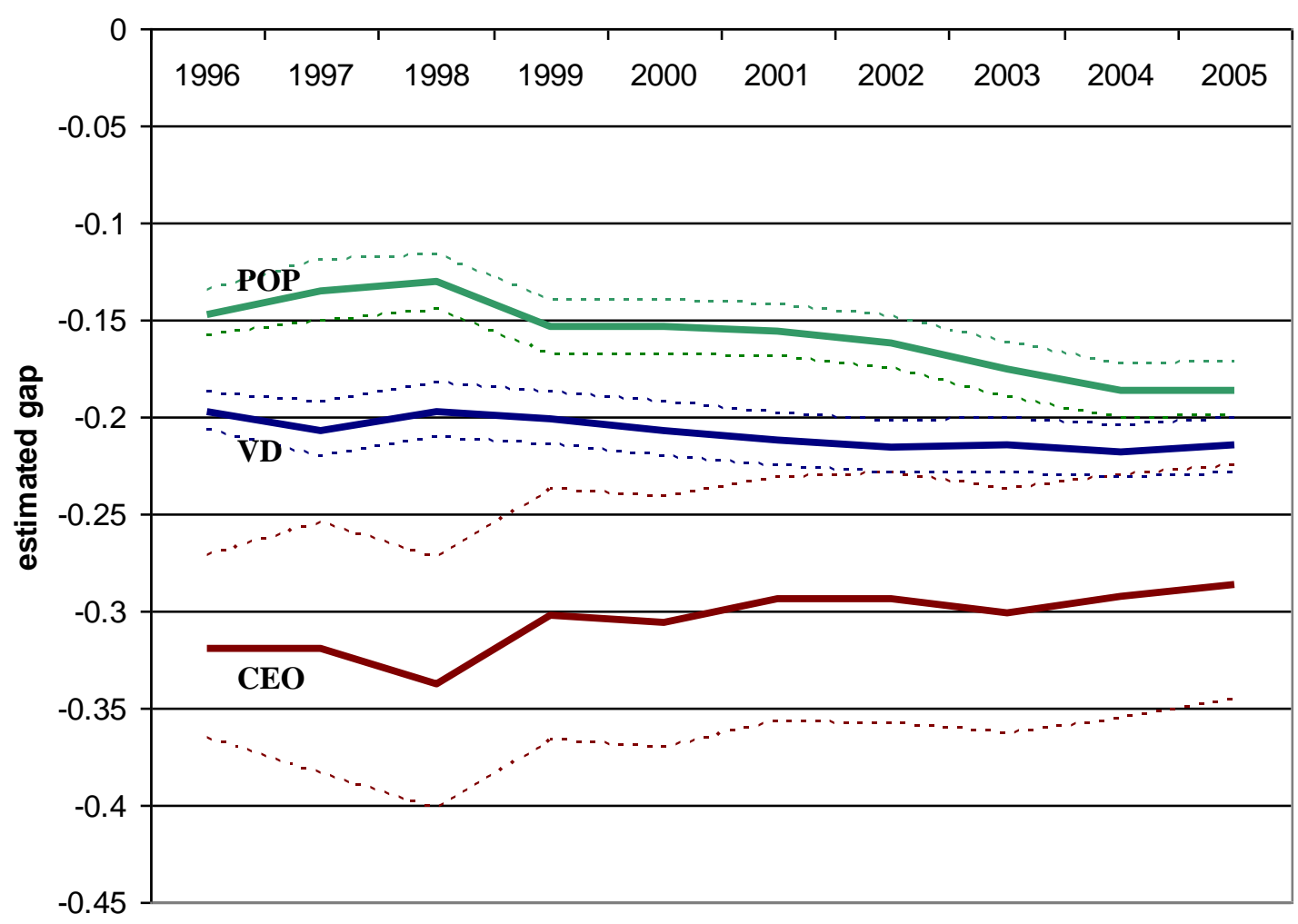

1.Panel estimates (FEVD) of the coefficients of $F+F^{*} D_{t}$. The dotted lines indicate $95 \%$ confidence bands.

According to Figure 1 the estimated gender compensation gap in 1996 was around $-0.15,-0.20$ and -0.32 for the Pool of potentials, VDs, and CEOs, respectively. During the period 10-year-period 1996-2005, the compensation gap increased (significantly) by 3.9 log points in the pool of 
potentials, $1.8 \mathrm{log}$ points among VDs. However, for CEOs the trend was different. Here, the estimated gap decreased by $3.3 \mathrm{log}$ points. The latter figure is not statistically significant which may be because of the large estimated variance on the estimated coefficients because of the very few female CEO observations.

It is interesting to note that the development in Figure 1 is remarkable different from the 'raw' gender gap figures in Table 2 which showed a substantial reduction for CEOs (from 36 percent to 13 percent) and smaller reductions for VD and potential executives. For the two latter groups, our estimates indicate a significant increase in the estimated compensation gap, not a reduction. For CEOs, the estimated gender gap reduction is much smaller than the raw figures indicate. Thus, the results show some signs of small 'cracks in the glass ceiling' in Denmark during the period 19962005 - though the ceiling still seems to exist and be fairly thick! However, lower down in the occupational hierarchy, the 'floors have become even more sticky', i.e. the compensation gap has widened.

\section{Gender specific estimations}

Until now, the estimated models have assumed the same coefficients to male and female characteristics, except the constant term, which is clearly rejected by the data when performing simple F-tests of equality of coefficients. Therefore, gender specific panel data models are estimated in order to allow for gender specific remuneration to observed characteristics. Selected results from Fixed Effects estimations are shown in Tables 7. The fixed effect estimator is applied here because we are interested in the effects from time varying variables. Full estimations are given in Appendix Table A2.

In general, the results clearly indicate that the compensation functions for female CEOs and to a smaller extent VDs are quite different compared to the group of female potential top executives. It is well known from many studies of the gender wage gap, for Denmark see for instance Gupta, Smith and Stratton (2007), that men tend to have steeper career profiles (i.e. higher remuneration to experience in the early career but then more flat later in the career compared to women), children and marriage have little effect on male wages and may sometimes even increase their earnings through a 'marriage premium' while women often incur a 'child penalty'. However, when estimating separate functions for the more narrow groups of top executives, the picture seems to be somewhat different from the 'traditional' human capital gender wage gap studies. For female CEOs 
we do not find any significant effects of children, while male CEOs are estimated to get a negative compensation shock of 2.8 percent the first years after they become fathers. The results for the female CEOS also deviate from the parallel results for females in the Pool of Potentials and to a smaller degree Vice-Director for whom the child variables have much more negative effects on compensation, more in line with traditional human capital wage functions. Female CEOs do on average have one child, as their male colleagues, see Table 3, and apparently - conditionally on having succeeded to reach a CEO position - they do not incur a 'child penalty'. ${ }^{12}$ We explain this finding as a further indication that women who reach the top of the firm and pass the 'glass ceiling' are highly selected and very different with respect to a number of unobserved characteristics compared to other women. E.g. for women in the Pool of Potentials and to some extent ViceDirector children still have a clear negative effect on their compensation but no or even a positive effect for men in these groups. Hence our results may reflect that before reaching the CEO level, women has "paid" their child penalty in terms of compensation, and eventually, a lower likelihood of promotion (not studied into detail in this study).

Table 7. Selected Coefficients from FE Estimations of Gender Specific Earnings Functions. 1996-2005.

\begin{tabular}{|c|c|c|c|c|c|c|}
\hline & \multicolumn{2}{|c|}{ Pool of potentials } & \multicolumn{2}{|c|}{ Vice-Director } & \multicolumn{2}{|c|}{ CEOs } \\
\hline & Male & Female & Male & Female & Male & Female \\
\hline Child aged 0-2 (0/1) & $\begin{array}{l}0.009 a \\
(0.004)\end{array}$ & $\begin{array}{c}-0.110 * \\
(0.007)\end{array}$ & $\begin{array}{c}-0.013 * \\
(0.003)\end{array}$ & $\begin{array}{c}-0.057^{*} \\
(0.009)\end{array}$ & $\begin{array}{c}-0.028^{*} \\
(0.009)\end{array}$ & $\begin{array}{c}0.018 \\
(0.051)\end{array}$ \\
\hline 1 child $(0 / 1)$ & $\begin{array}{c}0.004 \\
(0.004)\end{array}$ & $\begin{array}{c}-0.073^{*} \\
(0.009)\end{array}$ & $\begin{array}{l}0.007 \not a \\
(0.003)\end{array}$ & $\begin{array}{c}-0.025^{*} \\
(0.009)\end{array}$ & $\begin{array}{l}-0.010 \\
(0.008)\end{array}$ & $\begin{array}{c}0.060 \\
(0.059)\end{array}$ \\
\hline 2 children $(0 / 1)$ & $\begin{array}{c}0.009 \\
(0.005)\end{array}$ & $\begin{array}{c}-0.156^{*} \\
(0.012)\end{array}$ & $\begin{array}{l}0.018^{*} \\
(0.004)\end{array}$ & $\begin{array}{c}-0.031 * \\
(0.012)\end{array}$ & $\begin{array}{c}0.010 \\
(0.011)\end{array}$ & $\begin{array}{c}0.082 \\
(0.081)\end{array}$ \\
\hline $3+$ children $(0 / 1)$ & $\begin{array}{l}-0.000 \\
(0.008)\end{array}$ & $\begin{array}{c}-0.234^{*} \\
(0.019)\end{array}$ & $\begin{array}{l}0.030^{*} \\
(0.006)\end{array}$ & $\begin{array}{c}-0.081 * \\
(0.021)\end{array}$ & $\begin{array}{c}0.007 \\
(0.016)\end{array}$ & $\begin{array}{l}-0.074 \\
(0.134)\end{array}$ \\
\hline Spouse: CEO (Excl. 'single') & $\begin{array}{l}0.028^{*} \\
(0.009)\end{array}$ & $\begin{array}{c}0.002 \\
(0.010)\end{array}$ & $\begin{array}{l}0.016 \mathrm{a} \\
(0.008)\end{array}$ & $\begin{array}{l}0.024 \alpha \\
(0.012)\end{array}$ & $\begin{array}{l}0.038 \mathrm{q} \\
(0.019)\end{array}$ & $\begin{array}{l}-0.174 * \\
(0.051)\end{array}$ \\
\hline Share of women in firm & $\begin{array}{c}-0.166^{*} \\
(0.021)\end{array}$ & $\begin{array}{c}-0.111^{*} \\
(0.038)\end{array}$ & $\begin{array}{l}0.036^{*} \\
(0.013)\end{array}$ & $\begin{array}{c}0.023 \\
(0.034)\end{array}$ & $\begin{array}{l}-0.091 * \\
(0.037)\end{array}$ & $\begin{array}{l}-0.132 \\
(0.182)\end{array}$ \\
\hline Women on board $(0 / 1)$ & $\begin{array}{c}0.001 \\
(0.003)\end{array}$ & $\begin{array}{c}0.001 \\
(0.006)\end{array}$ & $\begin{array}{c}0.003 \\
(0.002)\end{array}$ & $\begin{array}{c}0.002 \\
(0.005)\end{array}$ & $\begin{array}{c}0.005 \\
(0.005)\end{array}$ & $\begin{array}{c}-0.014 \\
(0.027)\end{array}$ \\
\hline Female CEO $(0 / 1)$ & $\begin{array}{c}-0.023^{*} \\
(0.005)\end{array}$ & $\begin{array}{c}-0.052^{*} \\
(0.011)\end{array}$ & $\begin{array}{l}-0.007 \\
(0.004)\end{array}$ & $\begin{array}{c}0.002 \\
(0.011)\end{array}$ & - & - \\
\hline Female VD $(0 / 1)$ & $\begin{array}{l}-0.008^{*} \\
(0.002)\end{array}$ & $\begin{array}{c}-0.009000 \\
(0.005 *)\end{array}$ & - & - & - & - \\
\hline
\end{tabular}

* Significant at 1 percent, $\not \mathfrak{a}$ significant at 5 percent, 00 significant at 10 percent

\footnotetext{
${ }^{12}$ Holst and Busch (2009) find the same results in a study on German top executives.
} 
A crucial question is of course whether our estimates of child effects can be interpreted as causal effects. If the estimations in Table 7 still suffer from endogenity problems, whether due to omitted variables or reverse causality, we expect the child coefficients to be biased downwards. Since the estimates for female CEOs are positive (insignificant), the positive/insignificant estimates are lower bounds on the effects of children. However, the large and negative child effects for females in the pool of potential executives (and to a smaller extent VDs) may overestimate the negative compensation effects of children. The same holds for the variables reflecting being single and the indicators for the career position of the spouse, i.e. occupational variables. With these reservations in mind, it is interesting to note the numerically large negative (highly significant) coefficient in the female CEO-regression for being married to a CEO spouse. The estimations indicate that female CEOs married to or cohabiting with a husband who is also a CEO earns 17 percent less than single females in CEO position, cet. par.

Firms with a high share of females among the employees pay lower salaries to managers below Vice-director and CEO level (controlling for industry and other firm characteristics) and male CEOs, but female CEOs are apparently not punished for being employed in a female dominated firm. Exactly the same pattern is found for Germany in the study by Holst and Busch (2009) while Cardoso and Winter-Ebner (2007) find that a high female share only affects female top executives negatively in Portuguese firms.

Finally, contrary to other recent empirical findings for the US and Portugal, see Bell (2005) and Cardoso and Winter-Ebner (2007), our results do not confirm any hypothesis on firms being 'female friendly' by being 'female-led', either because of a female CEO or having at least one woman on the board of directors. The coefficients are either insignificant or significantly negative, also for the female executives ${ }^{13}$.

\section{Discussion and conclusion}

The proportion of women in executive positions is low in Denmark compared to many other countries. In 1996, only 3 percent of the CEOs in private firms were women. However, during the period 1996-2005, the female share among VDs and CEOs increased substantially, and also the

\footnotetext{
${ }^{13}$ In alternative estimation not shown we have estimated the same model but including firm specific fixed effects instead of individual specific effect. These estimations show the same results with respect to the variables representing female led firms.
} 
group of potential top executives became more gender balanced during this period. The 'raw' gender compensation gap among the executives included in this study was reduced from 35 percent to 31 percent between 1996 and 2005.

The gender compensation gap among Danish executives is estimated by applying a number of alternative panel estimators. The results in this study indicate that there still exists a considerable gender gap in compensation after controlling for a large number of observable factors for both individuals and firms and estimating panel models which also control for unobserved time constant heterogeneity. Especially the small group of female CEOs receives a much lower compensation compared to their male CEO colleagues. For this group, the indicator for being female is estimated to be -0.30 . For VDs and potential top executives the female coefficient is estimated to -0.21 and 0.16, respectively. Thus, comparing to the results found in other countries, in Denmark there is still a considerable glass ceiling, defined as a large estimated compensation gap for CEOs, but also evidence of sticky floors, defined as a statistically significant and substantial compensation gap among potential CEOs, here defined as the Pool of Potential and Vice-Directors.

During the period 1996 to 2005, the estimated gender compensation gap increased, especially among potential top executives, but also for VDs. For CEOs, the estimated compensation gap is slightly reduced during the period. Thus the results are mixed with respect to the answer whether the 'glass ceiling' is cracking and the 'sticky floors' are becoming less sticky in Denmark. On one hand, the female proportions in the three groups of executives analysed in this study have clearly been increasing, indicating that women have become more able to reach top positions. On the other hand, with regards to remuneration, females are still not able to crack the glass ceiling. During the period, the estimated gender compensation gap even increased for the potential executives. This evidence may reflect that the floors have become more 'sticky'.

The results in this study may be unexpected and does not point to large changes in women's position in the private sector in Denmark. The very low (though increasing) number of female CEOs in Danish private firms, a large estimated compensation gap, and the very moderate reduction of the gap for CEOs and even increasing gap for top executives below the level of CEO may come as a surprise. One potential explanation might be that some firms might permanently pay females (males) lower (higher) salaries, for instance due to variation in time constant preferences for discrimination or permanently gender biased information on skills and productivity, as proposed in 
the 'sticky floor' theory. We do find evidence of this behaviour in Danish firms. Controlling for unobserved firm specific effects, the estimated gender compensation gap is reduced by some percentage points compared to both simple OLS estimates and panel estimates which controls only for unobserved individual specific effects. However, even when controlling for such unobserved differences in firm behaviour there still exists a considerable compensation gap between male and female top executives and potential top executives of around 14 percent.

One explanation of the unexplained and stable compensation gap may be general effects of the universal and generous family friendly schemes, for instance maternity leave and care days for sick children, which in Denmark are mainly taken up by mothers (including female top executives), while fathers have not been using the schemes to far the same extent. As in many other European countries, the Danish maternity and parental leave schemes have been extended continuously since the mid 1980s and now amounts to 1 year per child with full or partly compensation and job protection, see Gupta, Smith and Verner (2008). These fairly generous schemes have ensured a constantly high fertility in the Nordic countries (the fertility rate in Denmark is 1.8), contrary to many other Western countries. In Denmark it is mainly mothers who take-up these leave periods while fathers' take-up rate has been stable around 5 percent. The same tendency is observed with respect to absence from work due to care for sick children and other care days.

Due to statistical discrimination mechanisms, the extension of the family friendly schemes may have had negative boomerang effects on the compensation and careers of all women, irrespective of whether they eventually become mothers or not. Especially for those women aiming to reach the top of the organization, these effects may be important because potential career interruptions are expected to be more severe for this group. Thus, when controlling for age and actual number of children and individual and firm specific unobserved factors as it is done in the estimations in this study, we may not catch the full effect of children on women's career and compensation. If all Danish women - even potential top executives - are expected by the employer to have 2 children and if virtually all mothers pick-up full maternity and parental leave of one year per child, this may be a major drawback for potential promotion and compensation for the female executives. It is not possible to control for these overall mechanisms which may be part of the explanations behind the large and stable unexplained compensation gaps found in this analysis because, by definition, the statistical discrimination effects will potentially affect all women. These effects will be included in the unexplained part of the gap, i.e. give indication of both 'sticky floors' and 'glass ceilings'. 


\section{References}

Angrist, D. J. and J.-S. Pischke (2009), Mostly Harmless Econometrics, Princeton University Press, New Jersey.

Bell, L. (2005), Women-Led Firms and the Gender Wage Gap in Top Executive Jobs, IZA DP no. 1689, Bonn.

Bechmann, K. L. (2008), Compensation of Executives in Denmark: Performance, Corporate Governance or Rent Extraction? Markets and Compensation for Executives in Europe, International Business and Management, vol 24, 263-286.

Bertrand, M. and K. Hallock (2001), Industrial and Labor Relations Review, vol. 55, 3-21.

Bertrand, M., C. Goldin, and L.F. Katz (2009), Dynamics of the Gender Gap for Younf Professionals in the Corporate and Financial Sectors, NBER Working Paper Series 14681, Cambridge MA.

Booth, A. L. (2009), Gender and competition, CEPR Discussion Paper 7437, London.

Booth, A. L., M. Francesconi, and J. Frank (2003), A sticky floors model of promotion, pay, and gender, European Economic Review, vol 47: 295-322.

Cardoso, A. R. and R. Winter-Ebner (2007), Mentoring and Segregation: Female-Led Firms and Gender Wage Policies, IZA DP No. 3210, Bonn.

Coate, S. and G. Loury (1993):"Will Affirmative-Action Policies Eliminate Negative Stereotypes?", American Economic Review 83, 1220-40.

Eriksson, T. (1999), Executive Compensation and Tournament Theory: Empirical Tests on Danish Data, Journal of Labor Economics, vol 17(2), 262-80.

Eriksson, T. (2001). How Common are The New Compensation and Work Organization Practices and Who Adopts Them? Working Paper 01-8, Aarhus School of Business - Department of Economics, Aarhus University.

EU Commission (2009), Report from the Commission to the Council, The European Parlament, The European Economic and Social Committee and the Committee of the Regions, Equality between women and men - 2009, Brussels

Gupta, D. N., R. Oaxaca and N. Smith (2006), Swimming Upstream, Floating Downstream: Comparing Women's Relative Wage Progress in the United States and Denmark, Industrial and Labor Relations, 59 (2), 243-66.

Gupta, N., N. Smith and L. Stratton (2007), Is Marriage Poisonous? Are Relationships Taxing? An Analysis of the Male Marital Wage Differential in Denmark, Southern Economic Journal, vol 74 (2), 412-433.

Gupta, N., N. Smith and M. Verner (2008), The impact of Nordic Countries' family friendly policies on employment, wages, and children, Review of Economics of the Household, 6:65-89.

Holst, E. and A. Busch (2009), Glass Ceiling Effect and Earnings - The Gender Pay Gap in Managerial Positions in Germany, SOEP paper 201, Berlin.

Hu, T. and Y. Myeong-Su (2008), Is the Glass Ceiling Cracking? A Simple Test, IZA DP no 3518, Bonn. 
Lazear, E. and S. Rosen (1981), Rank-Order Tournaments as Optimum Labor Contracts, Journal of Political Economy, Vol. 89 (5), 841-864.

Lazear, E. and S. Rosen (1990), Male-female wage differentials in job ladders, Journal of Labor Economics, vol 8: S106-S123.

Lundberg, S. (2005), Men and islands: Dealing with the family in empirical labor economics," Labour Economics, Elsevier, vol. 12(4), 591-612.

Murphy, K. J. (1999), Executive Compensation', in Ashenfelter, O. and D. Card (eds.), Handbook in Labor Economics. Elsevier, Amsterdam, North Holland, 2485-2563.

Niederle, M. and L. Vesterlund (2007), Do women shy away from competition? Do men compete too much? Quarterly Journal of Economics, 122(3), 1067-1101.

OECD (2002). Babies and Bosses, Reconciling work and family life, Paris.

Plümper, T. \& V. E. Troeger (2007): Efficient Estimation of Time-Invariant and Rarely Changing Variables in Finite Sample Panel Analyses with Unit Fixed Effects, in Political Analysis, 15(2), pp. 124-139.

Smith, N., V. Smith and M. Verner (2006), Do Women in Top Management Affect Firm Performance? A Panel Study of 2500 Danish Firms. International Journal of Productivity and Performance Management, Volume 55 (7), 569-593.

Terjesen, S. and V. Singh (2008), Female Presence on Corporate Boards: A Multi-Country Study of Environmental Context, Journal of Business Ethics, Springer, vol. 83(1), 55-63.

World Ecomomic Forum (2009), The Global Gender Gap Report, Geneva.

Yurtoglu, B. B. and C. Zulehner (2009a), Equity-based compensation and the gender pay gap in top corporate jobs. Mimeo. Austrian Institute of Economic Research, Vienna.

Yurtoglu, B. B. and C. Zulehner (2009b), Sticky floors and glass ceilings in top corporate jobs. Mimeo. Austrian Institute of Economic Research, Vienna. 
Appendix: Table A1. Sample means. 2005.

\begin{tabular}{|c|c|c|c|c|c|c|c|c|c|}
\hline & \multicolumn{3}{|c|}{ 'Pool of potentials' } & \multicolumn{2}{|c|}{ Vice-Director } & \multicolumn{4}{|c|}{ CEOs } \\
\hline & Male & Female & p-value & Male & Female & $\mathrm{p}$-value & Male & Female & $\mathrm{p}$-value \\
\hline \multicolumn{10}{|l|}{ Individual characteristics } \\
\hline Annual earnings $/ 1,000,000$ & $\begin{array}{c}0.49 \\
(0.25)\end{array}$ & $\begin{array}{c}0.38 \\
(0.16)\end{array}$ & $<0.001 *$ & $\begin{array}{c}0.71 \\
(0.38)\end{array}$ & $\begin{array}{c}0.59 \\
(0.26)\end{array}$ & $<0.001 *$ & $\begin{array}{c}1.32 \\
(0.88)\end{array}$ & $\begin{array}{c}1.15 \\
(0.90)\end{array}$ & 0.093 \\
\hline $\begin{array}{l}\text { Short further education } \\
(0 / 1)\end{array}$ & $\begin{array}{c}0.08 \\
(0.27)\end{array}$ & $\begin{array}{c}0.09 \\
(0.29)\end{array}$ & 0.055 & $\begin{array}{c}0.09 \\
(0.28)\end{array}$ & $\begin{array}{c}0.11 \\
(0.31)\end{array}$ & $<0.031 *$ & $\begin{array}{c}0.04 \\
(0.20)\end{array}$ & $\begin{array}{l}0.07 \\
(0.26)\end{array}$ & 0.488 \\
\hline $\begin{array}{l}\text { Medium length education } \\
(0 / 1)\end{array}$ & $\begin{array}{c}0.20 \\
(0.40)\end{array}$ & $\begin{array}{c}0.12 \\
(0.33)\end{array}$ & $<0.001 *$ & $\begin{array}{c}0.27 \\
(0.44)\end{array}$ & $\begin{array}{c}0.23 \\
(0.42)\end{array}$ & $<0.0021 *$ & $\begin{array}{c}0.33 \\
(0.47)\end{array}$ & $\begin{array}{l}0.16 \\
(0.37)\end{array}$ & $<0.001 *$ \\
\hline $\begin{array}{l}\text { Long further education } \\
(0 / 1)\end{array}$ & $\begin{array}{l}0.13 \\
(0.34\end{array}$ & $\begin{array}{c}0.14 \\
(0.35)\end{array}$ & 0.454 & $\begin{array}{c}0.18 \\
(0.38)\end{array}$ & $\begin{array}{c}0.21 \\
(0.41)\end{array}$ & 0.219 & $\begin{array}{c}0.26 \\
(0.44)\end{array}$ & $\begin{array}{c}0.31 \\
(0.46)\end{array}$ & 0.283 \\
\hline Work experience, years & $\begin{array}{l}21.43 \\
(10.95)\end{array}$ & $\begin{array}{l}17.12 \\
(9.64)\end{array}$ & $<0.001 *$ & $\begin{array}{l}22.93 \\
(9.70)\end{array}$ & $\begin{array}{l}20.26 \\
(9.11)\end{array}$ & $<0.001 *$ & $\begin{array}{c}24,22 \\
(10,33)\end{array}$ & $\begin{array}{l}23.64 \\
(8.88)\end{array}$ & 0.557 \\
\hline \multicolumn{10}{|l|}{$\begin{array}{l}\text { Work experience, } \\
\text { years } / 1,000\end{array}$} \\
\hline Child aged $0-2(0 / 1)$ & $\begin{array}{c}0.13 \\
(0.34)\end{array}$ & $\begin{array}{c}0.17 \\
(0.38)\end{array}$ & $<0.001 *$ & $\begin{array}{c}0.11 \\
(0.32)\end{array}$ & $\begin{array}{c}0.10 \\
(0.30)\end{array}$ & $<0.246$ & $\begin{array}{c}0.07 \\
(0.26)\end{array}$ & $\begin{array}{c}0.02 \\
(0.15)\end{array}$ & 0.009 \\
\hline 1 child $(0 / 1)$ & $\begin{array}{c}0.17 \\
(0.37)\end{array}$ & $\begin{array}{c}0.21 \\
(0.41)\end{array}$ & $<0.001 *$ & $\begin{array}{c}0.17 \\
(0.38)\end{array}$ & $\begin{array}{c}0.19 \\
(0.39)\end{array}$ & $<0.075$ & $\begin{array}{c}0.16 \\
(0.37)\end{array}$ & $\begin{array}{c}0.12 \\
(0.32)\end{array}$ & 0.222 \\
\hline 2 children $(0 / 1)$ & $\begin{array}{c}0.24 \\
(0.42)\end{array}$ & $\begin{array}{c}0.25 \\
(0.43)\end{array}$ & 0.118 & $\begin{array}{c}0.29 \\
(0.46)\end{array}$ & $\begin{array}{c}0.27 \\
(0.45)\end{array}$ & 0.081 & $\begin{array}{c}0.25 \\
(0.43)\end{array}$ & $\begin{array}{c}0.23 \\
(0.43)\end{array}$ & 0.919 \\
\hline $3+$ children $(0 / 1)$ & $\begin{array}{c}0.08 \\
(0.27)\end{array}$ & $\begin{array}{c}0.05 \\
(0.21)\end{array}$ & $<0.001 *$ & $\begin{array}{c}0.11 \\
(0.31)\end{array}$ & $\begin{array}{c}0.06 \\
(0.23)\end{array}$ & $<0.001 *$ & $\begin{array}{c}0.09 \\
(0.29)\end{array}$ & $\begin{array}{c}0.09 \\
(0.28)\end{array}$ & 0.93 \\
\hline Single & $\begin{array}{c}0.16 \\
(0.37)\end{array}$ & $\begin{array}{c}0.24 \\
(0.43)\end{array}$ & $<0.001 *$ & $\begin{array}{c}0.10 \\
(0.31)\end{array}$ & $\begin{array}{c}0.25 \\
(0.44)\end{array}$ & $<0.001 *$ & $\begin{array}{c}0.09 \\
(0.28)\end{array}$ & $\begin{array}{c}0.16 \\
(0.37)\end{array}$ & $<0.001 *$ \\
\hline \multicolumn{10}{|l|}{ Spouse characteristics } \\
\hline CEO $(0 / 1)$ & $\begin{array}{c}0.03 \\
(0.17)\end{array}$ & $\begin{array}{c}0.10 \\
(0.29)\end{array}$ & $<0.001 *$ & $\begin{array}{c}0.02 \\
(0.15)\end{array}$ & $\begin{array}{c}0.11 \\
(0.32)\end{array}$ & $<0.001 *$ & $\begin{array}{c}0.04 \\
(0.21)\end{array}$ & $\begin{array}{c}0.15 \\
(0.36)\end{array}$ & $0.021^{*}$ \\
\hline High level salaried $(0 / 1)$ & $\begin{array}{c}0.12 \\
(0.32)\end{array}$ & $\begin{array}{c}0.11 \\
(0.32)\end{array}$ & 0.785 & $\begin{array}{c}0.14 \\
(0.34)\end{array}$ & $\begin{array}{c}0.13 \\
(0.34)\end{array}$ & 0.560 & $\begin{array}{c}0.15 \\
(0.35)\end{array}$ & $\begin{array}{c}0.15 \\
(0.36)\end{array}$ & 0.757 \\
\hline Low level salaried $(0 / 1)$ & $\begin{array}{c}0.22 \\
(0.41)\end{array}$ & $\begin{array}{c}0.14 \\
(0.35)\end{array}$ & $<0.001 *$ & $\begin{array}{c}0.25 \\
(0.44)\end{array}$ & $\begin{array}{c}0.17 \\
(0.37)\end{array}$ & $<0.001 *$ & $\begin{array}{c}0.21 \\
(0.41)\end{array}$ & $\begin{array}{c}0.17 \\
(0.38)\end{array}$ & 0.168 \\
\hline Skilled (0/1) & $\begin{array}{c}0.27 \\
(0.45)\end{array}$ & $\begin{array}{c}0.18 \\
(0.38)\end{array}$ & $<0.001 *$ & $\begin{array}{c}0.25 \\
(0.43)\end{array}$ & $\begin{array}{c}0.13 \\
(0.34)\end{array}$ & $<0.001^{*}$ & $\begin{array}{c}0.19 \\
(0.39)\end{array}$ & $\begin{array}{c}0.09 \\
(0.28)\end{array}$ & $0.001 *$ \\
\hline Unskilled (0/1) & $\begin{array}{c}0.02 \\
(0.15)\end{array}$ & $\begin{array}{c}0.04 \\
(0.19)\end{array}$ & $<0,001 *$ & $\begin{array}{c}0.02 \\
(0.13)\end{array}$ & $\begin{array}{c}0.02 \\
(0.14)\end{array}$ & 0,401 & $\begin{array}{c}0.01 \\
(0.11)\end{array}$ & $\begin{array}{c}0.01 \\
(0.10)\end{array}$ & $<0.001 *$ \\
\hline Self-employed $(0 / 1)$ & $\begin{array}{c}0.02 \\
(0.15)\end{array}$ & $\begin{array}{c}0.04 \\
(0.20)\end{array}$ & $<0.001 *$ & $\begin{array}{c}0.03 \\
(0.17)\end{array}$ & $\begin{array}{c}0.05 \\
(0.22)\end{array}$ & $<.003 *$ & $\begin{array}{c}0.05 \\
(0.22)\end{array}$ & $\begin{array}{c}0.05 \\
(0.23)\end{array}$ & 0.787 \\
\hline Others $(0 / 1)$ & $\begin{array}{c}0.16 \\
(0.37)\end{array}$ & $\begin{array}{c}0.15 \\
(0.36)\end{array}$ & 0.261 & $\begin{array}{c}0.18 \\
(0.38)\end{array}$ & $\begin{array}{c}0.13 \\
(0.34)\end{array}$ & $<0.001 *$ & $\begin{array}{c}0.26 \\
(0.44)\end{array}$ & $\begin{array}{c}0.22 \\
(0.42)\end{array}$ & 0.315 \\
\hline \multicolumn{10}{|l|}{ Firm characteristics } \\
\hline Number of employees (log) & $\begin{array}{c}7.22 \\
(1.96)\end{array}$ & $\begin{array}{c}7.71 \\
(1.97)\end{array}$ & $<0.001 *$ & $\begin{array}{c}5.73 \\
(1.02)\end{array}$ & $\begin{array}{c}5.29 \\
(0.93)\end{array}$ & 0.21 & $\begin{array}{c}5.41 \\
(1.07)\end{array}$ & $\begin{array}{c}5.33 \\
(0.89)\end{array}$ & $0.011^{*}$ \\
\hline $\begin{array}{l}\text { Listed on stock exchange } \\
(0 / 1)\end{array}$ & $\begin{array}{c}0.09 \\
(0.28)\end{array}$ & $\begin{array}{c}0.08 \\
(0.27)\end{array}$ & $0.041^{*}$ & $\begin{array}{l}0.05 \\
(0.22)\end{array}$ & $\begin{array}{c}0.04 \\
(0.19)\end{array}$ & $0.018^{*}$ & $\begin{array}{c}0.07 \\
(0.26)\end{array}$ & $\begin{array}{c}0.10 \\
(0.30)\end{array}$ & 0.429 \\
\hline $\begin{array}{l}\text { Lagged performance } \\
\text { (ROE) }\end{array}$ & $\begin{array}{c}0.12 \\
(0.64)\end{array}$ & $\begin{array}{c}0.18 \\
(0.79)\end{array}$ & $<0.001 *$ & $\begin{array}{c}0.04 \\
(2.76)\end{array}$ & $\begin{array}{c}0.11 \\
(3.04)\end{array}$ & $<0.001 *$ & $\begin{array}{c}0.10 \\
(1.68)\end{array}$ & $\begin{array}{c}0.32 \\
(2.10)\end{array}$ & $<0.001 *$ \\
\hline Female share employees & $\begin{array}{c}0.32 \\
(0.13)\end{array}$ & $\begin{array}{c}0.41 \\
(0.14)\end{array}$ & $<0.001 *$ & $\begin{array}{c}0.30 \\
(0.15)\end{array}$ & $\begin{array}{c}0.44 \\
(0.19)\end{array}$ & $<0.001 *$ & $\begin{array}{c}0.32 \\
(0.16)\end{array}$ & $\begin{array}{c}0.41 \\
(0.18)\end{array}$ & $<0.001 *$ \\
\hline Energy $(0 / 1)$ & $\begin{array}{c}0.01 \\
(0.08)\end{array}$ & $\begin{array}{c}0.00 \\
(0.05)\end{array}$ & $0.020 *$ & $\begin{array}{c}0.00 \\
(0.07)\end{array}$ & $\begin{array}{l}0.002 \\
(0.04)\end{array}$ & $0.019 *$ & $\begin{array}{c}0.01 \\
(0.11)\end{array}$ & $\begin{array}{c}0.00 \\
(0.00)\end{array}$ & $<0.001 *$ \\
\hline $\begin{array}{l}\text { Building and construction } \\
(0 / 1)\end{array}$ & $\begin{array}{c}0.07 \\
(0.25)\end{array}$ & $\begin{array}{c}0.02 \\
(0.13)\end{array}$ & $<0.001 *$ & $\begin{array}{c}0.05 \\
(0.21)\end{array}$ & $\begin{array}{c}0.01 \\
(0.12)\end{array}$ & $<0.001 *$ & $\begin{array}{c}0.04 \\
(0.20)\end{array}$ & $\begin{array}{c}0.03 \\
(0.18)\end{array}$ & 0.691 \\
\hline Hotel, restaurant $(0 / 1)$ & $\begin{array}{c}0.31 \\
(0.46)\end{array}$ & $\begin{array}{c}0.45 \\
(0.50)\end{array}$ & $<0.001 *$ & $\begin{array}{c}0.27 \\
(0.44)\end{array}$ & $\begin{array}{c}0.35 \\
(0.48)\end{array}$ & $<0.001 *$ & $\begin{array}{c}0.27 \\
(0.45)\end{array}$ & $\begin{array}{c}0.30 \\
(0.46)\end{array}$ & 0.415 \\
\hline Transport, telecomm.(0/1) & $\begin{array}{c}0.06 \\
(0.23)\end{array}$ & $\begin{array}{c}0.09 \\
(0.28)\end{array}$ & $<0.001 *$ & $\begin{array}{c}0.06 \\
(0.25)\end{array}$ & $\begin{array}{l}0.08 \\
(0.27)\end{array}$ & 0.057 & $\begin{array}{c}0.07 \\
(0.26)\end{array}$ & $\begin{array}{c}0.12 \\
(0.32)\end{array}$ & 0.085 \\
\hline $\begin{array}{l}\text { Finance, private services } \\
(0 / 1)\end{array}$ & $\begin{array}{c}0.22 \\
(0.41)\end{array}$ & $\begin{array}{c}0.19 \\
(0.39)\end{array}$ & $<0.001 *$ & $\begin{array}{c}0.15 \\
(0.35)\end{array}$ & $\begin{array}{c}0.19 \\
(0.39)\end{array}$ & 0.008 & $\begin{array}{c}0.19 \\
(0.39)\end{array}$ & $\begin{array}{c}0.29 \\
(0.45)\end{array}$ & 0.117 \\
\hline Farming $(0 / 1)$ & $\begin{array}{c}0.05 \\
(0.21)\end{array}$ & $\begin{array}{c}0.02 \\
(0.12)\end{array}$ & $<0.001 *$ & - & - & & - & - & \\
\hline
\end{tabular}


Others

$\begin{array}{ll}0.00 & 0.00\end{array}$

(0.03)

$(0.03)$

Women-led firm char.

Female board member

$(0 / 1)$

Female CEO (0/1)

Female vice-director (0/1)

Number of observations

\begin{tabular}{ccccccccc}
0.16 & 0.18 & $0.001 *$ & 0.18 & 0.25 & $<0.001 *$ & 0.21 & 0.38 & $0.006^{*}$ \\
$(0.36)$ & $(0.39)$ & & $(0.39)$ & $(0.43)$ & & $(0.41)$ & $(0.49)$ & \\
0.07 & 0.08 & $<0.001 *$ & 0.05 & 0.10 & $<0.001 *$ & - & 1.00 & - \\
$(0.25)$ & $(0.27)$ & & $(0.23)$ & $(0.30)$ & & & $(0.00)$ & \\
0.41 & 0.48 & $<0.001 *$ & 0.47 & 1.00 & $<0.001 *$ & 0.39 & 0.56 & $0.008^{*}$ \\
$(0.49)$ & $(0.50)$ & & $(0.50)$ & $(0.00)$ & & $(0.49)$ & $(0.50)$ & \\
\hline 9,891 & 3,209 & & 7,212 & 1,049 & & 1,773 & 94 & \\
\hline
\end{tabular}


Table A2. FE Estimations of Gender Specific Earnings Functions. 1996-2005.

\begin{tabular}{|c|c|c|c|c|c|c|}
\hline & \multicolumn{2}{|c|}{ Pool of potentials } & \multicolumn{2}{|c|}{ Vice-Director } & \multicolumn{2}{|c|}{ CEOs } \\
\hline & Male & Female & Male & Female & Male & Female \\
\hline Experience, years & $\begin{array}{l}0.056^{*} \\
(0.001)\end{array}$ & $\begin{array}{l}0.074^{*} \\
(0.003)\end{array}$ & $\begin{array}{l}0.031^{*} \\
(0.001)\end{array}$ & $\begin{array}{l}0.027^{*} \\
(0.003)\end{array}$ & $\begin{array}{l}0.041^{*} \\
(0.003)\end{array}$ & $\begin{array}{l}0.084^{*} \\
(0.026)\end{array}$ \\
\hline Experience, squared/100 & $\begin{array}{l}-0.119^{*} \\
(0.002)\end{array}$ & $\begin{array}{l}-0.128^{*} \\
(0.005)\end{array}$ & $\begin{array}{l}-0.090^{*} \\
(0.001)\end{array}$ & $\begin{array}{l}-0.070 * \\
(0.005)\end{array}$ & $\begin{array}{l}-0.085^{*} \\
(0.005)\end{array}$ & $\begin{array}{l}-0.045 \\
(0.037)\end{array}$ \\
\hline $\begin{array}{l}\text { Education (Excl. 'vocational or } \\
\text { no education') }\end{array}$ & & & & & & \\
\hline Short tertiary education & $\begin{array}{c}0.027 \\
(0.023)\end{array}$ & $\begin{array}{l}0.073 \alpha \\
(0.033)\end{array}$ & $\begin{array}{l}0.050 \mathrm{\alpha} \\
(0.022)\end{array}$ & $\begin{array}{l}0.094 * \\
(0.033)\end{array}$ & $\begin{array}{l}-0.034 \\
(0.139)\end{array}$ & - \\
\hline Medium tertiary education & $\begin{array}{l}0.106^{*} \\
(0.028)\end{array}$ & $\begin{array}{l}0.080 \mathfrak{a} \\
(0.047)\end{array}$ & $\begin{array}{l}0.069 a \\
(0.028)\end{array}$ & $\begin{array}{l}0.210^{*} \\
(0.057)\end{array}$ & $\begin{array}{l}0.270 \mathfrak{\alpha} \\
(0.121)\end{array}$ & - \\
\hline $\begin{array}{l}\text { Long tertiary education } \\
\text { (university) }\end{array}$ & $\begin{array}{l}0.314 * \\
(0.041)\end{array}$ & $\begin{array}{l}0.483^{*} \\
(0.084)\end{array}$ & $\begin{array}{l}0.163 * \\
(0.033)\end{array}$ & $\begin{array}{l}0.191 \alpha \\
(0.077)\end{array}$ & - & - \\
\hline Child-variables: & & & & & & \\
\hline Child aged $0-2(0 / 1)$ & $\begin{array}{l}0.009 a \\
(0.004)\end{array}$ & $\begin{array}{l}-0.110^{*} \\
(0.007)\end{array}$ & $\begin{array}{l}-0.013 * \\
(0.003)\end{array}$ & $\begin{array}{l}-0.057 * \\
(0.009)\end{array}$ & $\begin{array}{l}-0.028 * \\
(0.009)\end{array}$ & $\begin{array}{c}0.018 \\
(0.051)\end{array}$ \\
\hline 1 child $(0 / 1)$ & $\begin{array}{c}0.004 \\
(0.004)\end{array}$ & $\begin{array}{l}-0.073^{*} \\
(0.009)\end{array}$ & $\begin{array}{l}0.007 a \\
(0.003)\end{array}$ & $\begin{array}{l}-0.025^{*} \\
(0.009)\end{array}$ & $\begin{array}{l}-0.010 \\
(0.008)\end{array}$ & $\begin{array}{c}0.060 \\
(0.059)\end{array}$ \\
\hline 2 children $(0 / 1)$ & $\begin{array}{c}0.009 \\
(0.005)\end{array}$ & $\begin{array}{l}-0.156^{*} \\
(0.012)\end{array}$ & $\begin{array}{l}0.018^{*} \\
(0.004)\end{array}$ & $\begin{array}{l}-0.031 * \\
(0.012)\end{array}$ & $\begin{array}{c}0.010 \\
(0.011)\end{array}$ & $\begin{array}{c}0.082 \\
(0.081)\end{array}$ \\
\hline $3+$ children $(0 / 1)$ & $\begin{array}{l}-0.000 \\
(0.008)\end{array}$ & $\begin{array}{l}-0.234^{*} \\
(0.019)\end{array}$ & $\begin{array}{l}0.030^{*} \\
(0.006)\end{array}$ & $\begin{array}{c}-0.081 * \\
(0.021)\end{array}$ & $\begin{array}{c}0.007 \\
(0.016)\end{array}$ & $\begin{array}{l}-0.074 \\
(0.134)\end{array}$ \\
\hline Spouse variables(Excl. 'single') & & & & & & \\
\hline Spouse: CEO & $\begin{array}{l}0.028^{*} \\
(0.009)\end{array}$ & $\begin{array}{c}0.002 \\
(0.010)\end{array}$ & $\begin{array}{l}0.016 \mathrm{q} \\
(0.008)\end{array}$ & $\begin{array}{l}0.024 \alpha \\
(0.012)\end{array}$ & $\begin{array}{l}0.038 \not \alpha \\
(0.019)\end{array}$ & $\begin{array}{c}-0.174 * \\
(0.051)\end{array}$ \\
\hline Spouse: Salaried, High level & $\begin{array}{l}0.039 * \\
(0.007)\end{array}$ & $\begin{array}{l}-0.010 \\
(0.011)\end{array}$ & $\begin{array}{l}-0.000 \\
(0.005)\end{array}$ & $\begin{array}{c}0.006 \\
(0.012)\end{array}$ & $\begin{array}{c}0.002 \\
(0.014)\end{array}$ & $\begin{array}{l}-0.011 \\
(0.063)\end{array}$ \\
\hline Spouse: Salaried, Low level & $\begin{array}{l}0.033^{*} \\
(0.005)\end{array}$ & $\begin{array}{l}-0.016 \\
(0.010)\end{array}$ & $\begin{array}{l}-0.002 \\
(0.004)\end{array}$ & $\begin{array}{l}-0.006 \\
(0.010)\end{array}$ & $\begin{array}{l}-0.004 \\
(0.013)\end{array}$ & $\begin{array}{c}0.059 \\
(0.063)\end{array}$ \\
\hline Spouse: Skilled & $\begin{array}{l}0.024^{*} \\
(0.005)\end{array}$ & $\begin{array}{c}-0.019 a \\
(0.008)\end{array}$ & $\begin{array}{l}-0.010 \\
(0.004)\end{array}$ & $\begin{array}{c}0.005 \\
(0.010)\end{array}$ & $\begin{array}{c}0.013 \\
(0.013)\end{array}$ & $\begin{array}{l}-0.027 \\
(0.056)\end{array}$ \\
\hline Spouse: Unskilled & $\begin{array}{l}0.020 \not \alpha \\
(0.009)\end{array}$ & $\begin{array}{l}-0.008 \\
(0.014)\end{array}$ & $\begin{array}{l}-0.010 \\
(0.007)\end{array}$ & $\begin{array}{c}0.006 \\
(0.017)\end{array}$ & $\begin{array}{l}-0.009 \\
(0.026)\end{array}$ & $\begin{array}{c}0.112 \\
(0.136)\end{array}$ \\
\hline Spouse: Self-employed & $\begin{array}{c}0.006 \\
(0.011)\end{array}$ & $\begin{array}{c}-0.041^{*} \\
(0.015)\end{array}$ & $\begin{array}{c}0.008 \\
(0.007)\end{array}$ & $\begin{array}{l}-0.009 \\
(0.015)\end{array}$ & $\begin{array}{c}0.009 \\
(0.016)\end{array}$ & $\begin{array}{l}-0.082 \\
(0.076)\end{array}$ \\
\hline Spouse: Other & $\begin{array}{l}0.012 \alpha \\
(0.005)\end{array}$ & $\begin{array}{c}-0.018 \mathfrak{a} \\
(0.009)\end{array}$ & $\begin{array}{l}-0.003 \\
(0.004)\end{array}$ & $\begin{array}{c}0.013 \\
(0.010)\end{array}$ & $\begin{array}{c}0.065 \\
(0.012)\end{array}$ & $\begin{array}{c}0.087 \\
(0.052)\end{array}$ \\
\hline Firm variables & & & & & & \\
\hline Log firm size (employees) $(0 / 1)$ & $\begin{array}{l}0.018^{*} \\
(0.002)\end{array}$ & $\begin{array}{l}0.011 * \\
(0.003)\end{array}$ & $\begin{array}{l}0.031 * \\
(0.002)\end{array}$ & $\begin{array}{l}0.030^{*} \\
(0.006)\end{array}$ & $\begin{array}{l}0.050^{*} \\
(0.005)\end{array}$ & $\begin{array}{c}0.041 \\
(0.036)\end{array}$ \\
\hline Listed on stock exchange $(0 / 1)$ & $\begin{array}{l}0.012 \alpha \\
(0.006)\end{array}$ & $\begin{array}{l}0.024000 \\
(0.013)\end{array}$ & $\begin{array}{c}0.003 \\
(0.005)\end{array}$ & $\begin{array}{c}0.025 \\
(0.021)\end{array}$ & $\begin{array}{c}0.011 \\
(0.014)\end{array}$ & $\begin{array}{c}0.156 \\
(0.111)\end{array}$ \\
\hline Female share employees & $\begin{array}{c}-0.166^{*} \\
(0.021)\end{array}$ & $\begin{array}{l}-0.111^{*} \\
(0.038)\end{array}$ & $\begin{array}{l}0.036^{*} \\
(0.013)\end{array}$ & $\begin{array}{c}0.023 \\
(0.034)\end{array}$ & $\begin{array}{c}-0.091 * \\
(0.037)\end{array}$ & $\begin{array}{l}-0.132 \\
(0.182)\end{array}$ \\
\hline Perfomance (ROE) & $\begin{array}{c}0.019 \\
(0.608)\end{array}$ & $\begin{array}{c}0.047 \\
(0.126)\end{array}$ & $\begin{array}{l}-0.047 \\
(0.030)\end{array}$ & $\begin{array}{l}-0.055 \\
(0.150)\end{array}$ & $\begin{array}{c}0.010 \\
(0.008)\end{array}$ & $\begin{array}{c}0.258 \\
(0.644)\end{array}$ \\
\hline Industry (Excl. manufacturing) & & & & & & \\
\hline Energy & $\begin{array}{c}0.061 \\
(0.050)\end{array}$ & $\begin{array}{c}0.016 \\
(0.092)\end{array}$ & $\begin{array}{c}0.037 \\
(0.029)\end{array}$ & $\begin{array}{c}0.072 \\
(0.099)\end{array}$ & $\begin{array}{l}0.241 * \\
(0.069)\end{array}$ & - \\
\hline Building \& Construction & $\begin{array}{l}-0.072 * \\
(0.016)\end{array}$ & $\begin{array}{c}0.017 \\
(0.043)\end{array}$ & $\begin{array}{l}-0.010 \\
(0.010)\end{array}$ & $\begin{array}{c}0.013 \\
(0.038)\end{array}$ & $\begin{array}{c}0.043000 \\
(0.026)\end{array}$ & - \\
\hline Trade & $\begin{array}{l}-0.022 * \\
(0.007)\end{array}$ & $\begin{array}{l}-0.029 \\
(0.018)\end{array}$ & $\begin{array}{c}0.005 \\
(0.004)\end{array}$ & $\begin{array}{c}0.019 \\
(0.013)\end{array}$ & $\begin{array}{c}0.013 \\
(0.012)\end{array}$ & $\begin{array}{c}0.144 \\
(0.115)\end{array}$ \\
\hline $\begin{array}{l}\text { Transportation \& } \\
\text { telecommunication }\end{array}$ & $\begin{array}{c}0.006 \\
(0.014)\end{array}$ & $\begin{array}{c}0.051 \\
(0.032)\end{array}$ & $\begin{array}{c}0.012 \\
(0.011)\end{array}$ & $\begin{array}{l}-0.030 \\
(0.035)\end{array}$ & $\begin{array}{l}0.080 \mathrm{\alpha} \\
(0.034)\end{array}$ & $\begin{array}{l}0.449000 \\
(0.242)\end{array}$ \\
\hline $\begin{array}{l}\text { Financial sector and other private } \\
\text { services }\end{array}$ & $\begin{array}{l}-0.005 \\
(0.007)\end{array}$ & $\begin{array}{c}0.008 \\
(0.019)\end{array}$ & $\begin{array}{l}0.017 * \\
(0.004)\end{array}$ & $\begin{array}{l}0.037 \not a \\
(0.015)\end{array}$ & $\begin{array}{c}0.007 \\
(0.012)\end{array}$ & $\begin{array}{c}0.025 \\
(0.099)\end{array}$ \\
\hline $\begin{array}{l}\text { Women-led } \\
\text { Women on board }(0 / 1)\end{array}$ & $\begin{array}{c}0.001 \\
(0.003)\end{array}$ & $\begin{array}{c}0.001 \\
(0.006)\end{array}$ & $\begin{array}{c}0.003 \\
(0.002)\end{array}$ & $\begin{array}{c}0.002 \\
(0.005)\end{array}$ & $\begin{array}{c}0.005 \\
(0.005) \\
\end{array}$ & $\begin{array}{l}-0.014 \\
(0.027)\end{array}$ \\
\hline
\end{tabular}




\begin{tabular}{|c|c|c|c|c|c|c|}
\hline Female CEO $(0 / 1)$ & $\begin{array}{c}-0.023 * \\
(0.005)\end{array}$ & $\begin{array}{c}-0.052 * \\
(0.011)\end{array}$ & $\begin{array}{l}-0.007 \\
(0.004)\end{array}$ & $\begin{array}{c}0.002 \\
(0.011)\end{array}$ & - & - \\
\hline Female VD $(0 / 1)$ & $\begin{array}{c}-0.008 * \\
(0.002)\end{array}$ & $\begin{array}{c}-0.009000 \\
\left(0.005^{*}\right)\end{array}$ & - & - & - & - \\
\hline Constant, Year dummies & Yes & Yes & Yes & Yes & Yes & Yes \\
\hline R square (overall) & 0.202 & 0.290 & 0.140 & 0.218 & 0.024 & 0.022 \\
\hline R square (within) & 0.236 & 0.249 & 0.355 & 0.378 & 0.200 & 0.266 \\
\hline R square (between) & 0.186 & 0.282 & 0.125 & 0.232 & 0.076 & 0.008 \\
\hline Number of observations & 74,353 & 21,799 & 73,942 & 8,328 & 19,495 & 769 \\
\hline
\end{tabular}

* Significant at 1 percent, $ם$ significant at 5 percent, 